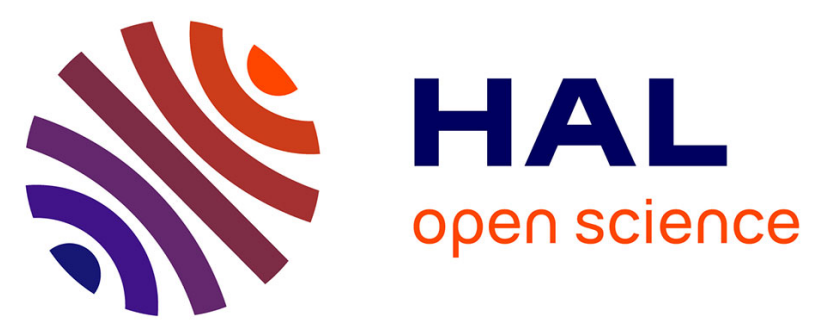

\title{
Exploiting the S4-S5 Specificity of Human Neutrophil Proteinase 3 to Improve the Potency of Peptidyl Di(chlorophenyl)-phosphonate Ester Inhibitors: A Kinetic and Molecular Modeling Analysis
}

\author{
Carla Guarino, Natalia Gruba, Renata Grzywa, Edyta \\ Dyguda-Kazimierowicz, Yveline Hamon, Monika Ł gowska, Marcin Skoreński, \\ Sandrine Dallet-Choisy, Adam Marchand-Adam, Christine Kellenberger, et al.
}

\section{- To cite this version:}

Carla Guarino, Natalia Gruba, Renata Grzywa, Edyta Dyguda-Kazimierowicz, Yveline Hamon, et al.. Exploiting the S4-S5 Specificity of Human Neutrophil Proteinase 3 to Improve the Potency of Peptidyl Di(chlorophenyl)-phosphonate Ester Inhibitors: A Kinetic and Molecular Modeling Analysis. Journal of Medicinal Chemistry, 2018, 61 (5), pp.1858-1870. 10.1021/acs.jmedchem.7b01416 . hal-02094546

\section{HAL Id: hal-02094546 \\ https://hal-amu.archives-ouvertes.fr/hal-02094546}

Submitted on 9 Apr 2019

HAL is a multi-disciplinary open access archive for the deposit and dissemination of scientific research documents, whether they are published or not. The documents may come from teaching and research institutions in France or abroad, or from public or private research centers.
L'archive ouverte pluridisciplinaire HAL, est destinée au dépôt et à la diffusion de documents scientifiques de niveau recherche, publiés ou non, émanant des établissements d'enseignement et de recherche français ou étrangers, des laboratoires publics ou privés. 


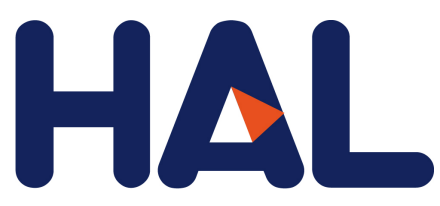

archives-ouvertes

\title{
Exploiting the S4-S5 Specificity of Human Neutrophil Proteinase 3 to Improve the Potency of Peptidyl Di(chlorophenyl)-phosphonate Ester Inhibitors: A Kinetic and Molecular Modeling Analysis
}

\author{
Carla Guarino, Natalia Gruba, Renata Grzywa, Edyta \\ Dyguda-Kazimierowicz, Yveline Hamon, Monika Ł gowska, Marcin Skoreński, \\ Sandrine Dallet-Choisy, Adam Marchand-Adam, Christine Kellenberger, et al.
}

\section{- To cite this version:}

Carla Guarino, Natalia Gruba, Renata Grzywa, Edyta Dyguda-Kazimierowicz, Yveline Hamon, et al.. Exploiting the S4-S5 Specificity of Human Neutrophil Proteinase 3 to Improve the Potency of Peptidyl Di(chlorophenyl)-phosphonate Ester Inhibitors: A Kinetic and Molecular Modeling Analysis. Journal of Medicinal Chemistry, American Chemical Society, 2018, 61 (5), pp.1858-1870. 10.1021/acs.jmedchem.7b01416 . hal-02094546

\section{HAL Id: hal-02094546 \\ https://hal-amu.archives-ouvertes.fr/hal-02094546}

Submitted on 9 Apr 2019

HAL is a multi-disciplinary open access archive for the deposit and dissemination of scientific research documents, whether they are published or not. The documents may come from teaching and research institutions in France or abroad, or from public or private research centers.
L'archive ouverte pluridisciplinaire HAL, est destinée au dépôt et à la diffusion de documents scientifiques de niveau recherche, publiés ou non, émanant des établissements d'enseignement et de recherche français ou étrangers, des laboratoires publics ou privés. 


\section{Exploiting the S4-S5 Specificity of Human Neutrophil Proteinase 3 ${ }_{2}$ to Improve the Potency of Peptidyl Di(chlorophenyl)-phosphonate ${ }_{3}$ Ester Inhibitors: A Kinetic and Molecular Modeling Analysis}

${ }_{4}$ Carla Guarino, ${ }^{\dagger}$ Natalia Gruba, ${ }^{\dagger}$ Renata Grzywa, ${ }^{\S}$ Edyta Dyguda-Kazimierowicz, ${ }^{\text {I }}$ Yveline Hamon, ${ }^{\dagger}$ ${ }_{5}$ Monika Legowska, ${ }^{\dagger}$ Marcin Skoreński, ${ }^{\S}$ Sandrine Dallet-Choisy, ${ }^{\dagger}$ Sylvain Marchand-Adam, ${ }^{\dagger}$ ${ }_{6}$ Christine Kellenberger, ${ }^{\perp}$ Dieter E. Jenne, ${ }^{\#}$ Marcin Sienczyk, ${ }^{\S}$ Adam Lesner, ${ }^{\ddagger}$ Francis Gauthier, ${ }^{\dagger}$ 7 and Brice Korkmaz ${ }^{*}, \dagger$

$8{ }^{\dagger}$ INSERM U-1100, “Centre d’Etude des Pathologies Respiratoires”, Université François Rabelais, 37032 Tours, France

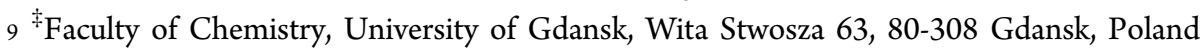

$10{ }^{\S}$ Faculty of Chemistry, Division of Medicinal Chemistry and Microbiology, Wroclaw University of Science and Technology, Wyb.

11 Wyspianskiego 27, 50-370 Wroclaw, Poland

12 "Faculty of Chemistry, Advanced Materials Engineering and Modelling Group, Wroclaw University of Science and Technology, Wyb.

13 Wyspianskiego 27, 50-370 Wroclaw, Poland

${ }_{14}{ }^{\perp}$ Architecture et Fonction des Macromolécules Biologiques, CNRS-Unité Mixte de Recherche (UMR), 13288 Marseille, France

15 \#Institute of Lung Biology and Disease, German Center for Lung Research (DZL), Comprehensive Pneumology Center Munich and

16 Max Planck Institute of Neurobiology, 82152 Planegg-Martinsried, Germany

17 S Supporting Information

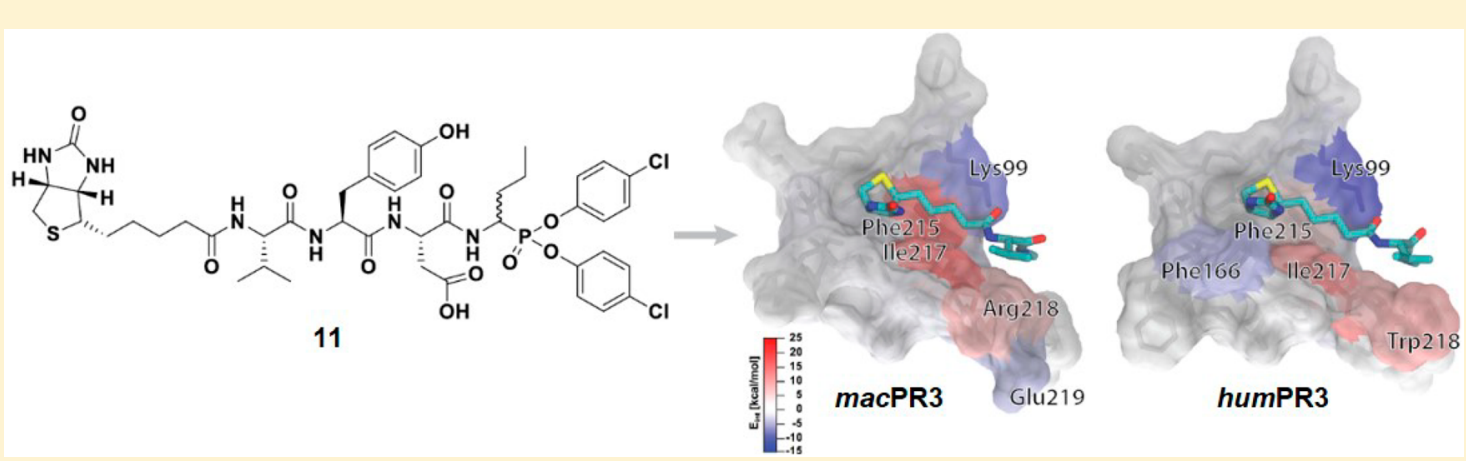

18 ABSTRACT: The neutrophilic serine protease proteinase 3 (PR3) is involved in inflammation and immune response and thus 19 appears as a therapeutic target for a variety of infectious and inflammatory diseases. Here we combined kinetic and molecular 20 docking studies to increase the potency of peptidyl-diphenyl phosphonate PR3 inhibitors. Occupancy of the S1 subsite of PR3 by 21 a nVal residue and of the S4-S5 subsites by a biotinylated Val residue as obtained in biotin- $-\mathrm{VYDnV}^{\mathrm{P}}\left(\mathrm{O}-\mathrm{C}_{6} \mathrm{H}_{4}-4-\mathrm{Cl}\right)_{2}$ enhanced 22 the second-order inhibition constant $k_{\mathrm{obs}} /[\mathrm{I}]$ toward PR3 by more than 10 times $\left(k_{\mathrm{obs}} /[\mathrm{I}]=73000 \pm 5000 \mathrm{M}^{-1} \mathrm{~s}^{-1}\right)$ as compared 23 to the best phosphonate PR3 inhibitor previously reported. This inhibitor shows no significant inhibitory activity toward human 24 neutrophil elastase and resists proteolytic degradation in sputa from cystic fibrosis patients. It also inhibits macaque PR3 but not the PR3 from rodents and can thus be used for in vivo assays in a primate model of inflammation.

\section{INTRODUCTION}

27 Polymorphonuclear neutrophil phagocytes are characterized by 28 the presence of abundant intracytoplasmic granules rich in 29 antimicrobial peptides and proteins involved in innate 30 immunity. ${ }^{1,2}$ Azurophilic granules also store four neutrophil 31 serine proteases (NSPs): proteinase 3 (PR3), elastase (NE), 32 cathepsin G (CG), and neutrophil serine protease 4 (NSP-4), 33 which are released into the environment in response to 34 inflammatory stimuli. ${ }^{1,3}$ An excess of proteases may be released, 35 however, during chronic inflammation which disrupts the 36 protease-protease inhibitor balance and accelerates proteolysis of the extracellular matrix. ${ }^{4,5}$ The administration of exogenous 37 inhibitors targeting these proteases may thus be an excellent 38 therapeutic strategy to fight inflammation. ${ }^{5,6}$ Although the total 39 amount of PR3 in neutrophils is similar to that of NE or CG, its 40 activity is by far less controlled by endogenous inhibitors. ${ }^{7} 41$ Indeed, there is no specific endogenous inhibitor of human PR3 42 (humPR3) and one of its more potent inhibitors, $\alpha-1-43$ proteinase inhibitor $(\alpha 1 \mathrm{PI})$, interacts about 100 times less 44 


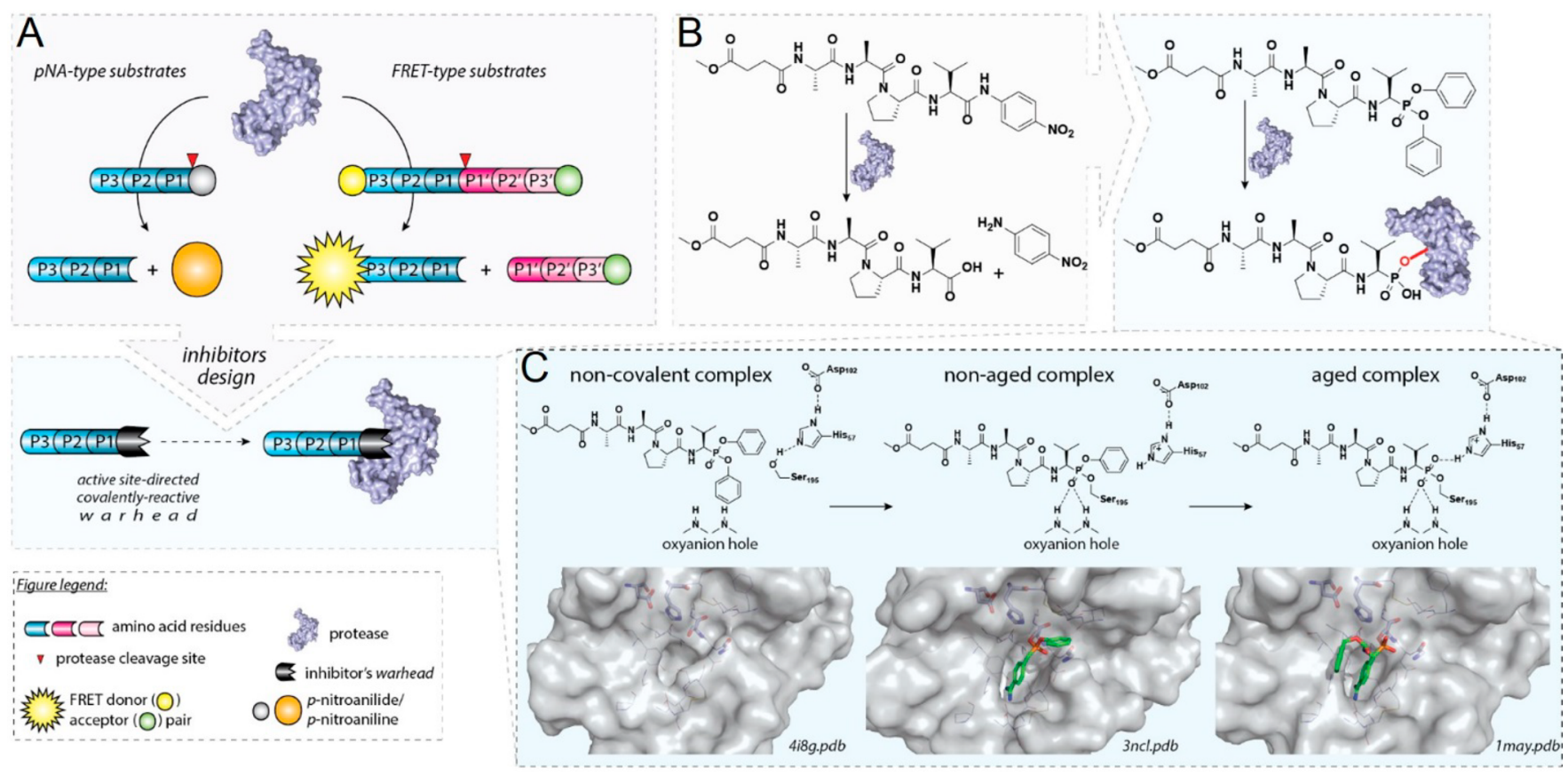

Figure 1. Design, structure, and mechanism of action of 1-aminoalkylphosphonate diaryl ester inhibitors. (A) General strategy of a substrate-based approach for covalent inhibitors development. (B) Development of a peptidyl-phosphonate inhibitor. (C) Mechanism of serine proteases inhibition by 1-aminoalkylphosphonate diaryl esters together with crystal structures of bovine trypsin (Protein Data Bank (PDB) 4I8G and 1MAY) and human matriptase (PDB 3NCL) at different stages of aging process.

45 rapidly with humPR3 than with humNE. ${ }^{7}$ Further, the 46 pathophysiological role of humPR3 is less well understood 47 than that of the related humNE and CG. Its function as 48 autoantigen in granulomatosis with polyangiitis ${ }^{8-10}$ and its 49 likely involvement in neutrophil apoptosis ${ }^{11}$ makes it different 50 from its closest homologue humNE.

51 humPR3 closely resembles humNE structurally and func52 tionally with a highly conserved catalytic triad (His57, Asp102, 53 and Ser195 residues (chymotrypsinogen numbering)) located 54 between two similar domains each comprising a six-stranded $\beta$ 55 barrel. ${ }^{12}$ Its $\mathrm{pI}$, however, is somewhat less basic than that of 56 humNE. ${ }^{5,13}$ Several residues on the loops surrounding the 57 protease active site assist the catalytic process. Most 58 importantly, the backbone amide hydrogens of Gly193 and 59 Ser195 that define the oxyanion hole and are located near the 60 carbonyl group of the substrate's scissile bond, stabilizing the 61 developing partial charge on the tetrahedral intermediate 62 during catalysis. ${ }^{14}$

63 The structural analysis of the active site of humPR3 and 64 hum NE showed that the distribution of charged residues close 65 to the substrate binding site (99 loop, 60 loop, 37 loop, and 66 autolysis loop) of these two proteases differs notably. ${ }^{15}$ Thus, 67 humPR3 contains three charged residues Lys99, Asp61, and 68 Arg143 in the active site region. ${ }^{12}$ The S1 binding pocket of 69 humPR3 and humNE is hemispherical, therefore, both 70 preferentially accommodate small hydrophobic residues at the ${ }_{71} \mathrm{P} 1$ position (according to the nomenclature of Schechter and 72 Berger (Schechter and Berger, 1967)).,13 The S2 subsite of 73 humPR3 differs from that of humNE by the presence of a 74 solvent accessible Lys at position 99, favoring accommodation 75 of negatively charged or polar P2 residues in the deep S2 76 subsite of PR3. ${ }^{12}$ The Leu99 residue in humNE makes the S2 77 pocket more hydrophobic. The Lys99 of humPR3 is conserved 78 in the PR3 of higher primates and many artiodactyls but not in 79 PR3 of New World monkeys and rodents, whereas the Leu99 of humNE is highly conserved in many other species. ${ }^{7}$ This 80 makes the PR3 specificity of these latter species different from 81 that of humPR3 and explains that rodents are not an 82 appropriate animal model for studies related to the biological 83 activity of humPR3. Another critical residue that makes the 84 specificities of humPR3 and hum NE different is that at position 85 217 in the vicinity of the S4 subsite, where an Ile in humPR3 is 86 replaced by an Arg in humNE. ${ }^{16,17}$

87

We have designed and synthesized selective peptidyl- 88 diphenyl phosphonate inhibitors based on these structural 89 differences between humPR3 and hum NE using the sequence of 90 an optimized peptide substrate of PR3. ${ }^{18}$ Phosphonate 91 inhibitors are peptide-based transition state irreversible 92 inhibitors which form transition-state-resembling complexes 93 with serine proteases. ${ }^{19-21}$ The inhibition is initiated by the 94 formation of a noncovalent enzyme-inhibitor complex, which 95 upon the nucleophilic attack of the Ser195 on the phosphorus 96 atom loses one aryloxy group, forming an initial, irreversible 97 covalent complex (Figure 1). Further aging followed by $98 \mathrm{fl}$ hydrolysis of a second ester group leads to the formation of 99 an aged covalent protease-inhibitor complex stabilized by the 100 oxyanion hole. ${ }^{19}$ Phosphonate inhibitors are chemically stable 101 inhibitors that block selectively serine proteases at low 102 concentration under acidic or neutral conditions. ${ }^{22}$ Phospho- 103 nate inhibitors were designed and developed by anchoring of 104 the serine trap to the recognition sequence derived from a 105 peptidyl substrate of the target protease (Figure 1). These 106 inhibitors which interact covalently with the Ser195 of the 107 catalytic triad can also be used as activity-based probes $(\mathrm{ABP})^{23} 108$ to visualize membrane-bound or intracellular, proteolytically 109 active, serine proteases. ${ }^{24}$ Several peptidyl-diphenyl phospho- 110 nate inhibitors of humPR3 have been developed but all were 111 more potent toward hum $\mathrm{NE}^{25,26}$ until we synthesized the first 112 selective chlorodiphenyl phosphonate humPR3 inhibitors, the 113 
Table 1. Rates of Inhibition of humPR3 and humNE by Peptide Phosphonates

\begin{tabular}{|c|c|c|c|c|}
\hline \multirow[b]{3}{*}{ compd } & \multirow[b]{3}{*}{ peptide phosphonate esters } & \multirow[b]{3}{*}[\mathrm{I}]{$\mu \mathrm{M}$} & \multicolumn{2}{|c|}{ proteases } \\
\hline & & & \multicolumn{2}{|c|}{$k_{\mathrm{obs}} /[\mathrm{I}]\left(\mathrm{M}^{-1} \mathrm{~s}^{-1}\right)^{a}$} \\
\hline & & & humPR3 & humNE \\
\hline 1 & Ac-Pro-Tyr-Asp-AlaP(O- $\left.\mathrm{C}_{6} \mathrm{H}_{4}-4-\mathrm{Cl}\right)_{2}$ & 2 & $154 \pm 3^{b}$ & $\mathrm{~ns}$ \\
\hline 2 & Bt-Pro-Tyr-Asp-AlaP(O- $\left.\mathrm{C}_{6} \mathrm{H}_{4}-4-\mathrm{Cl}\right)_{2}$ & 0.06 & $4168 \pm 553^{\#}$ & $\mathrm{~ns}$ \\
\hline 3 & Bt-[PEG]2-Pro-Tyr-Asp-AlaP $\left(\mathrm{O}-\mathrm{C}_{6} \mathrm{H}_{4}-4-\mathrm{Cl}\right)_{2}$ & 0.6 & $274 \pm 12$ & $\mathrm{~ns}$ \\
\hline 4 & Bt-Val-Tyr-Asp-AlaP $\left(\mathrm{O}-\mathrm{C}_{6} \mathrm{H}_{4}-4-\mathrm{Cl}\right)_{2}$ & 0.025 & $17396 \pm 835$ & ns \\
\hline 5 & Bt-Leu-Tyr-Asp-AlaP $\left(\mathrm{O}-\mathrm{C}_{6} \mathrm{H}_{4} 4-\mathrm{Cl}\right)_{2}$ & 0.15 & $4371 \pm 652$ & $\mathrm{~ns}$ \\
\hline 6 & Bt-Ile-Tyr-Asp-AlaP $\left(\mathrm{O}-\mathrm{C}_{6} \mathrm{H}_{4}-4-\mathrm{Cl}\right)_{2}$ & 0.15 & $8698 \pm 658$ & ns \\
\hline 7 & Bt-nLeu-Tyr-Asp-AlaP $\left(\mathrm{O}-\mathrm{C}_{6} \mathrm{H}_{4}-4-\mathrm{Cl}\right)_{2}$ & 0.025 & $10361 \pm 766$ & $\mathrm{~ns}$ \\
\hline 8 & Bt-nLeu $(O$-Bzl $)-$ Tyr-Asp-AlaP $\left(\mathrm{O}-\mathrm{C}_{6} \mathrm{H}_{4}-4-\mathrm{Cl}\right)_{2}$ & 0.1 & $1744 \pm 164$ & $\mathrm{~ns}$ \\
\hline 9 & Bt-Pro-Tyr-Asp-AbuP $\left(\mathrm{O}-\mathrm{C}_{6} \mathrm{H}_{4}-4-\mathrm{Cl}\right)_{2}$ & 0.1 & $4675 \pm 438$ & ns \\
\hline 10 & Bt-Pro-Tyr-Asp-nValP(O- $\left.\mathrm{C}_{6} \mathrm{H}_{4}-4-\mathrm{Cl}\right)_{2}$ & 0.025 & $18642 \pm 705$ & ns \\
\hline 11 & Bt-Val-Tyr-Asp-nValP(O- $\left.\mathrm{C}_{6} \mathrm{H}_{4}-4-\mathrm{Cl}\right)_{2}$ & 0.01 & $73258 \pm 5342$ & $\mathrm{~ns}$ \\
\hline
\end{tabular}

$114 \mathrm{~N}$-biotinylation of which allows using them $\mathrm{ABP}$ to visualize 115 active humPR3 in biological samples. ${ }^{\text {is }}$

116 Application of PR3 inhibitors as therapeutic tools requires 117 that they easily reach and interact with their target protease 118 with great specificity, they resist degradation during their 119 administration and in situ, and their half-life in the organism is 120 significant. Using inhibitors as therapeutic tools also requires 121 that a relevant animal model is available for preclinical studies. 122 In this work, we first designed and developed new biotin123 peptidyl $\mathrm{P}^{\mathrm{P}}\left(\mathrm{O}-\mathrm{C}_{6} \mathrm{H}_{4}-4-\mathrm{Cl}\right)_{2}$ inhibitors with improved potency of 124 action toward humPR3 to use them as versatile pharmacological 125 tools for assessing protease function in vivo. We focused on 126 improving the rate constant for inactivation $\left(k_{\mathrm{obs}} /[\mathrm{I}]\right)$ by 127 molecular docking trials and on analyzing structure-activity 128 relationships (SAR) to optimize efficacy at a very low dose and 129 thus make the resulting compound effective for a pharmaco130 logical application. Because PR3 from rodents retain a substrate 131 specificity that differs from that of human, ${ }^{27}$ we then looked for 132 a relevant in vivo model of inflammation and tested 133 phosphonate inhibitors on the PR3 from Macaca fascicularis.

\section{$134 \square$ RESULTS}

135 Stabilizing Properties of a Biotinylated N-Terminal P4 136 Residue in PR3 Substrates and Inhibitors. Replacing the $137 \mathrm{~N}$-terminal acetyl group by biotin $(\mathrm{Bt})$ in Ac-PYDA ${ }^{\mathrm{P}}\left(\mathrm{O}-\mathrm{C}_{6} \mathrm{H}_{4}\right.$ $1384-\mathrm{Cl})_{2}(1)$ to give $\mathrm{Bt}-\mathrm{PYDA}^{\mathrm{P}}\left(\mathrm{O}-\mathrm{C}_{6} \mathrm{H}_{4}-4-\mathrm{Cl}\right)_{2}$ (2) significantly 139 improved the $k_{\text {obs }} /[\mathrm{I}]$ value $^{18}\left(4168 \mathrm{M}^{-1} \mathrm{~s}^{-1}\right.$ vs $\left.154 \mathrm{M}^{-1} \mathrm{~s}^{-1}\right)$ 140 (Table 1) and significantly improved the $K_{\mathrm{i}}$ value of the initial 141 noncovalent complex ( 21 vs $3600 \mathrm{nM}$ ) (Table 2). Accordingly, 142 the substitution of the N-terminal acetyl group by a biotin in 143 the paranitroanilide (pNA) substrate Ac-PYDA-pNA increased 144 the specificity constant $k_{\text {cat }} / K_{\mathrm{m}}$ by $\sim 6$-fold (Table 3 ). We 145 employed a computational docking approach to explain how 146 biotin could modulate the interaction between Bt-PYDA ${ }^{\mathrm{P}}(\mathrm{O}$ $\left.147 \mathrm{C}_{6} \mathrm{H}_{4}-\mathrm{Cl}\right)_{2}$ and the active site of PR3 (Figure 2A,B). The lowest 148 energy binding mode obtained in the docking studies of 2 with 149 humPR3 revealed that the biotin moiety is located in the S5 150 pocket limited by the Lys99, Phe166, Cys168, Arg177, and 151 Ile217 residues (Figure $2 \mathrm{~B}$ ). The entrance into this pocket is 152 guarded by the Lys99 side chain with its $\varepsilon$-amino group, 153 creating a hydrogen bonding with the carbonyl oxygen of the 154 Bt-Pro4 amide bond. This interaction would facilitate the 155 correct orientation of both Pro4 and biotin in the S4 and S5 156 binding sites, respectively. The arrangement of Phe166,
Table 2. Rates of Inhibition of humPR3 by Peptide Phosphonates

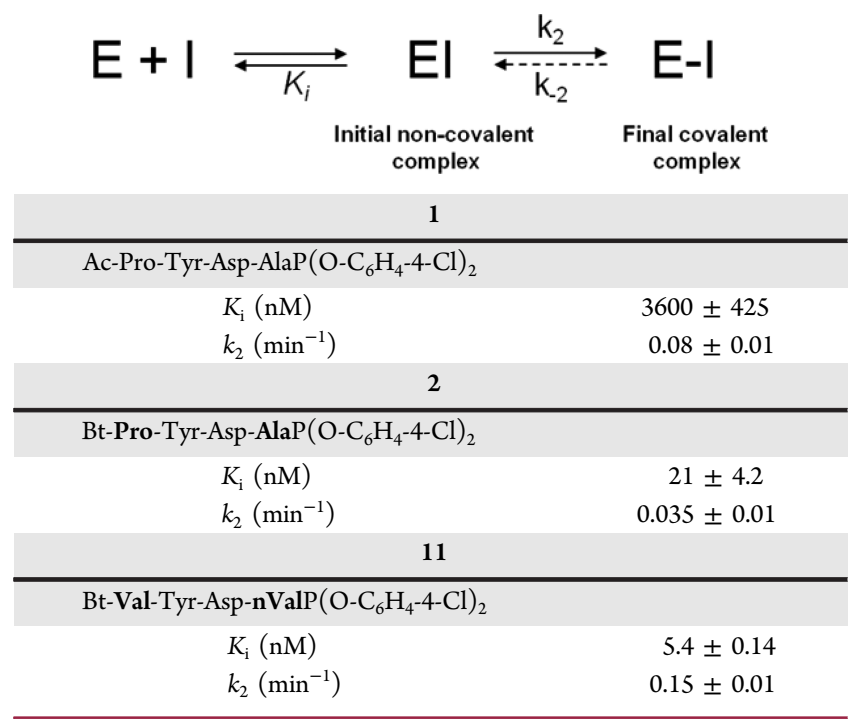

Table 3. Kinetics of Synthetic Substrate Cleavage by humPR3 and hum NE

\begin{tabular}{lccc} 
& & \multicolumn{2}{c}{ proteases } \\
\cline { 3 - 4 } \multicolumn{1}{c}{ pNA substrates } & {$[\mathrm{S}] \mathrm{mM}$} & $k_{\text {cat }} / K_{\mathrm{m}}\left(\mathrm{M}^{-1} \mathrm{~s}-1\right)^{a}$ \\
\cline { 3 - 4 } Ac-Pro-Tyr-Asp-Ala-pNA & 1 & $4201 \pm 29.7^{b}$ & humNE \\
Bt-Pro-Tyr-Asp-Ala-pNA & 1 & $25080 \pm 141.4$ & $\mathrm{nh}$ \\
Bt-Val-Tyr-Asp-Ala-pNA & 1 & $34965 \pm 99$ & $\mathrm{nh}$ \\
Bt-Val-Tyr-Asp-nVal-pNA & 1 & $80510 \pm 2973$ & $\mathrm{nh}$
\end{tabular}

${ }^{a}$ Values are means $\pm \mathrm{SD}$ of three experiments. ${ }^{b}$ Value was taken from ref 18. Definition of abbreviation: nh, not hydrolyzed

Cys168, and Arg177 residues in the S5 subsite creates the 157 cavity that accommodates the biotin heterocyclic rings (Figure 158 2B). The stabilizing role of biotin was confirmed by introducing 159 a polyethylene glycol $[\mathrm{PEG}]_{2}$ spacer between the $\mathrm{P} 4$ residue 160 Pro and biotin $\left(\mathrm{Bt}-[\mathrm{PEG}]_{2}-\mathrm{PYDA}^{\mathrm{P}}\left(\mathrm{O}-\mathrm{C}_{6} \mathrm{H}_{4}-4-\mathrm{Cl}\right)_{2}\right.$ (3), which 161 resulted in a dramatic fall of the $k_{\text {obs }} /[\mathrm{I}]$ (Table 1). The docking 162 model shows that the length of the biotin moiety is optimal for 163 the binding in the S5 pocket, and any spacer between the Pro4 164 and biotin would not improve the interaction. A biotin at P5 165 

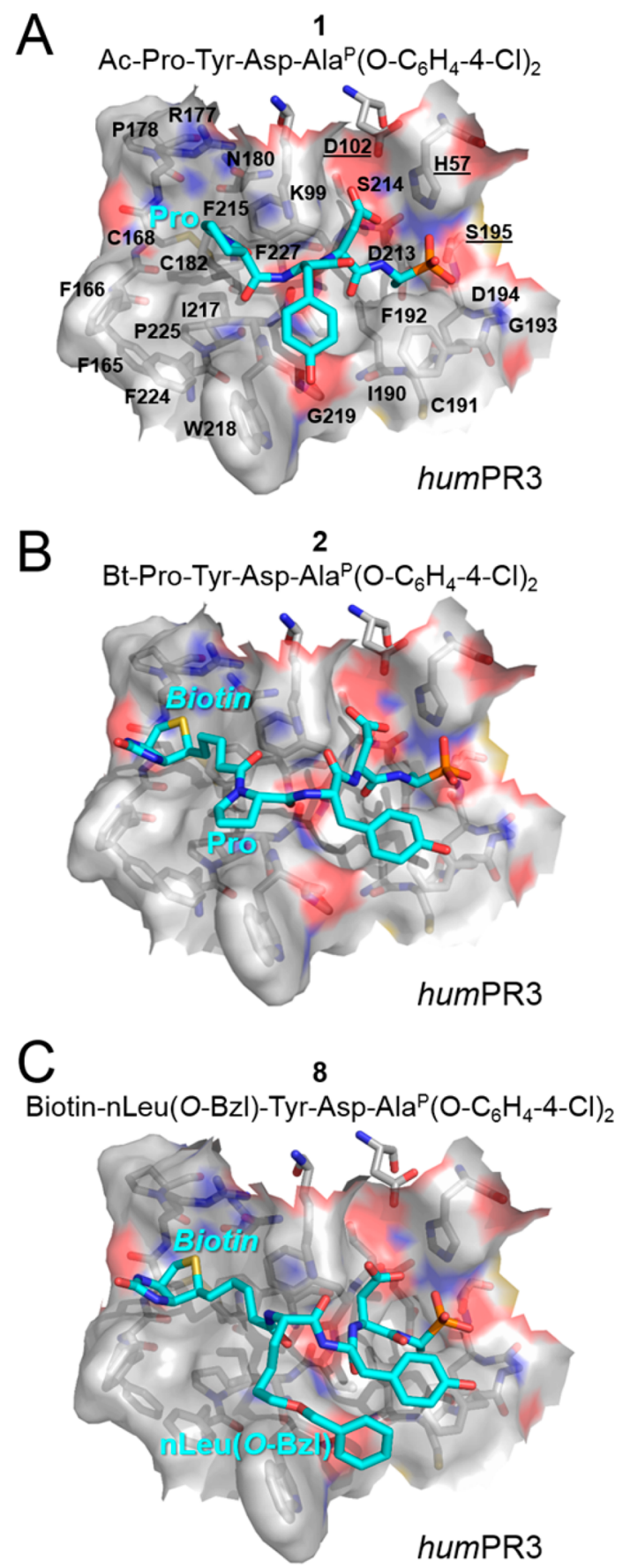

Figure 2. Proposed putative model of 1 (A), 2 (B), and 8 (C) binding to the active site of humPR3. The solvent-accessible surface area of the active site in humPR3 (PDB $1 \mathrm{FUJ}^{12}$ ) was made transparent to allow the visualization of the residues in stick representation. The singleletter code of residues in the vicinity of the active site is indicated in black. Residues are labeled following the numbering of chymotrypsin. The residues of the catalytic triad H57, D102, and S195 are underlined. The carbon atoms of PR3 and the compounds are shown in white and cyan, respectively. The oxygen, nitrogen, sulfur, and phosphorus atoms are colored in red, blue, yellow, and orange, respectively.

166 was thus retained for the construction of new inhibitors with a 167 modified peptidyl sequence.

168 Influence of the P4 Residue on the Inhibitory Activity 169 of Bt-Peptidyl $\mathrm{P}^{\mathrm{P}}\left(\mathrm{O}-\mathrm{C}_{6} \mathrm{H}_{4}-4-\mathrm{Cl}\right)_{2}$ Phosphonate Inhibitors. 170 The computational docking study showed that the $\mathrm{P} 4$ residue
Pro in 2 was close to solvent accessible hydrophobic Trp218 in 171 PR3 (Figure 2B). We replaced the P4 Pro by Val (4), Leu (5), 172 Ile (6), and norleucine (nLeu) (7) to tentatively optimize the 173 interaction with the PR3 hydrophobic patch build by residues 174 Phe166, Ile217, Phe224, and possibly with Trp218. While Leu 175 or Ile at P4 position decreased the inhibitory activity toward 176 PR3, the presence of nLeu or Val improved the inhibitory 177 activity by $\sim 2$ and $\sim 4$ times, respectively (Table 1 ). 178 Accordingly, the specificity constant $k_{\text {cat }} / K_{\mathrm{m}}$ of the pNA 179 substrate Bt-VYDA-pNA was also improved (Table 3). 180 Whatever the substitution at P4 in phosphonate inhibitors 181 was, the resulting compound retained no significant inhibitory 182 activity toward humNE although this protease also prefers a 183 hydrophobic residue at this position. Because the S4 subsite is 184 composed mainly by side chains of Trp218 and Ile217 and the 185 distinctly hydrophobic area (Phe166, Phe224) span beyond this 186 position, we decided to probe the existence of interactions by 187 substitution $\mathrm{nLeu}$ by $\mathrm{nLeu}(\mathrm{O}-\mathrm{Bzl})$ at $\mathrm{P} 4 \mathrm{in} 7(\mathbf{8})$. However, this 188 resulted in more than 10 times lower $k_{\text {obs }} /[\mathrm{I}]$ value (Table 1 ). 189 Moreover, the molecular docking model did not confirm the 190 interaction between $\mathrm{nLeu}(\mathrm{O}-\mathrm{Bzl})$ and, as mentioned above, a 191 distant hydrophobic area. In fact, the P4 side chain of 8 makes 192 contact mainly with Trp218 (Figure 2C). The comparison with 193 the 2 model (Figure 2B) indicates that the introduction of 194 more sizable $\mathrm{nLeu}(\mathrm{O}-\mathrm{Bzl})$ group at $\mathrm{P} 4$ does not alter the overall 195 mode of binding but affects the placement of inhibitor 196 backbone at the S4 subsite, thus preventing hydrogen bond 197 formation between Lys99 and the carbonyl oxygen of the Bt- 198 $\mathrm{nLeu}(\mathrm{O}-\mathrm{Bzl})$ amide (Figure 1C).

Influence of the P1 and P4 Residues on the Efficacy of 200 Bt-Peptidyl $\mathrm{P}\left(\mathrm{O}-\mathrm{C}_{6} \mathrm{H}_{4}-4-\mathrm{Cl}\right)_{2}$ Phosphonate Inhibitors. Un- 201 like the S2 subsite of PR3 that preferentially accommodates 202 negatively charged P2 residues and is thus essential to confer 203 PR3 selectivity, ${ }^{15}$ the S1 subsite in PR3 may accommodate a 204 variety of residues including norvaline ( $\mathrm{nVal}$ ) and aminobutyric 205 acid (Abu) among the favorites. We substituted the P1 alanyl 206 residue in the parent inhibitor (2) by $\mathrm{Abu}$ and $\mathrm{nVal}$. Bt- 207 PYDA $^{\mathrm{P}}\left(\mathrm{O}-\mathrm{C}_{6} \mathrm{H}_{4}-4-\mathrm{Cl}\right)_{2}$ (2) and Bt-PYDAbu ${ }^{\mathrm{P}}\left(\mathrm{O}-\mathrm{C}_{6} \mathrm{H}_{4}-4-\mathrm{Cl}\right)_{2} 208$ (9) showed similar efficacy toward PR3 (Table 1). However, 209 $\mathrm{Bt}-\mathrm{PYDnV}{ }^{\mathrm{P}}\left(\mathrm{O}-\mathrm{C}_{6} \mathrm{H}_{4}-4-\mathrm{Cl}\right)_{2}(10)$ was $\sim 4.5$ times more potent 210 than 2.

211

As expected, the substitution of Pro by Val at P4 in 10 (11) 212 significantly improved the $k_{\mathrm{obs}} /[\mathrm{I}]$ value, providing the best 213 inhibitor of the series with a $k_{\mathrm{obs}} /[\mathrm{I}]=73000 \pm 5000 \mathrm{M}^{-1} \mathrm{~s}^{-1} \cdot 214$ This 20-fold increase as compared to $\mathbf{1}$ resulted from a decrease 215 in the $K_{\mathrm{i}}$ value of the initial equilibrium between PR3 and Bt- 216 $\mathbf{V Y D n V}^{\mathrm{P}}\left(\mathrm{O}-\mathrm{C}_{6} \mathrm{H}_{4}-4-\mathrm{Cl}\right)_{2}(\mathbf{1 1})$ and an increase of the first-order 217 rate constant $k_{2}$ producing the final covalent complex (Table 218 2). Combining Val at P4 and $\mathrm{nVal}$ at $\mathrm{P} 1$ in the pNA substrate 219 Bt-VYDnV-pNA also significantly increased the specificity 220 constant toward PR3 (Table 3).

221

The computational docking approach employed to examine 222 the interaction between $\mathrm{Bt}-\mathrm{VYDnV}^{\mathrm{P}}\left(\mathrm{O}-\mathrm{C}_{6} \mathrm{H}_{4}-4-\mathrm{Cl}\right)_{2}$ and 223 humPR3 (Figure 3A) revealed that for the lowest energy $224 \mathrm{f} 3$ pose the overall mode of enzyme-inhibitor binding resembles 225 the one obtained for Bt-PYDA ${ }^{\mathrm{P}}\left(\mathrm{O}-\mathrm{C}_{6} \mathrm{H}_{4}-4-\mathrm{Cl}\right)_{2}(2)$. The biotin 226 aliphatic chain interacts with the hydrophobic surface of S5 227 subsite, while the biotin rings extend into the terminal cavity of 228 this subsite in the manner observed with Bt-PYDA ${ }^{\mathrm{P}}\left(\mathrm{O}-\mathrm{C}_{6} \mathrm{H}_{4}-4-229\right.$ $\mathrm{Cl})_{2}$. For both models, the $\mathrm{P} 4$ residue of inhibitor is located at 230 the narrow subsite with the Trp218 on one side and the Lys99 231 on the other. Therefore, increased inhibitory potency observed 232 for derivatives with Val instead of Pro at P4 may be due to an 233 

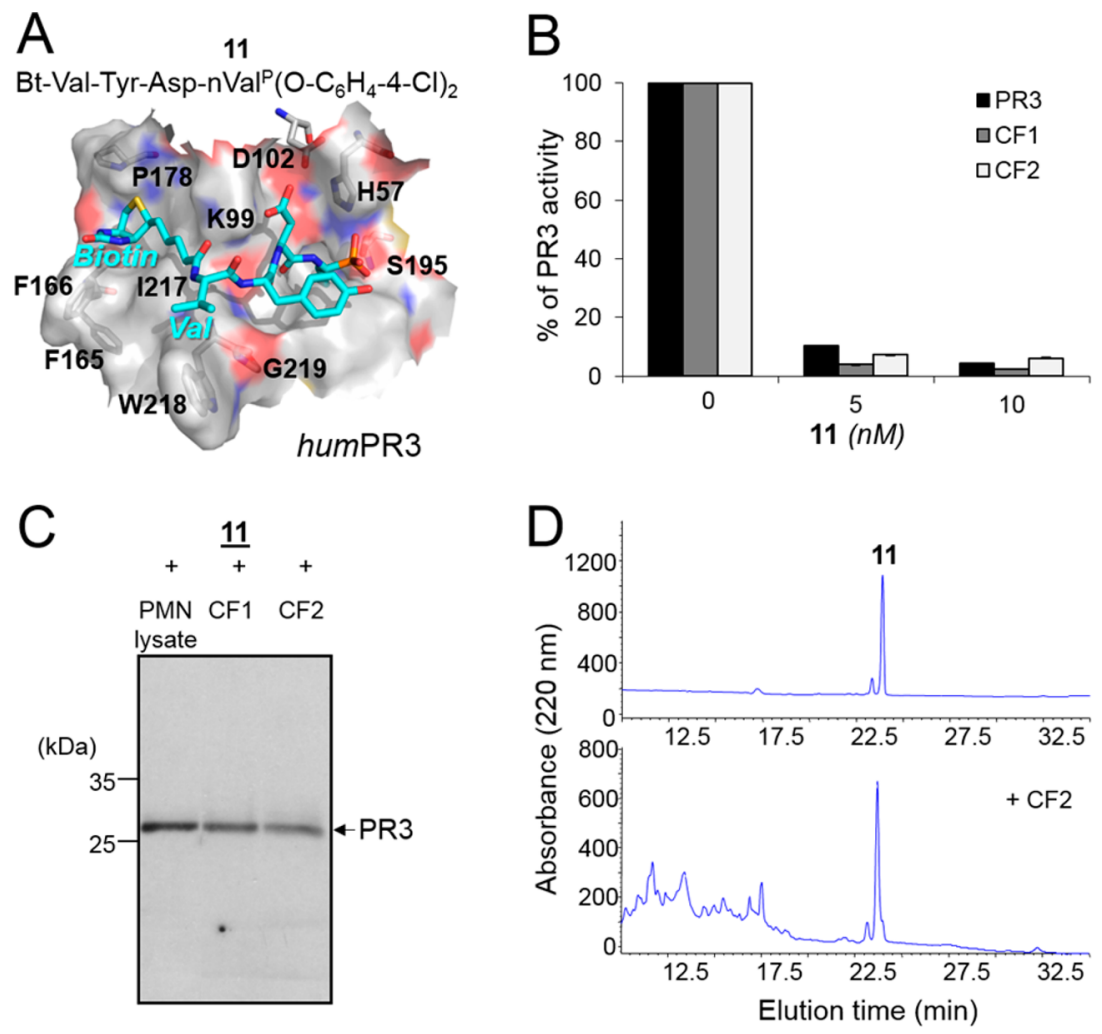

Figure 3. Inhibition of humPR3 and stability of $\mathbf{1 1}$ in the cell free supernatants of sputa from CF patients. (A) Proposed putative model of $\mathbf{1 1}$ in humPR3 active center. (B) Inhibition of PR3 in a representative CF sputum supernatants. The volume of CF sputum was adjusted to give final concentrations of PR3, $1 \mathrm{nM}$. Diluted samples were incubated with 11 (5 and $10 \mathrm{nM}$ final) for 20 min at $37^{\circ} \mathrm{C}$. Inhibition was monitored by measuring the residual activity of PR3 on ABZ-VADnVADYQ-EDDnp $(20 \mu \mathrm{M})$. Purified PR3 $(1 \mathrm{nM})$ was used as control. (C) Selective labeling of PR3 activity in CF sputum and neutrophil lysate. Samples (10 $\mu \mathrm{g}$ of total protein) were incubated for 20 min at $37{ }^{\circ} \mathrm{C}$ with 11 (50 nM), and the mixtures were analyzed by WB using extravidin-peroxidase. (D) HPLC profile of the 11 after a 120 min incubation time with samples showing the stability of the inhibitor in sputa from cystic fibrosis patients. Similar results were found in three independent experiments.

234 improved flexibility of this region upon enzyme-inhibitor 235 binding. The $\varepsilon$-amino group of Lys 99 forms hydrogen bonds 236 with Bt-Val4 amide carbonyl oxygen as well as Asp2 carboxyl 237 group. Additionally, quantum chemical calculations of inter238 action energy revealed that Lys 99 residue contributes the most 239 to binding of Bt-Val4 portion of the inhibitor, as the value of 240 the interaction energy due to the presence of this particular 241 residue amounts to $-16.6 \mathrm{kcal} / \mathrm{mol}$ (Table 4). Attracting 242 interactions between Bt-Val4 tail of $\mathbf{1 1}$ and PR3 residues were 243 also found for Phe166 and Val216 $(-3.8$ and $-1.6 \mathrm{kcal} / \mathrm{mol}$, 244 respectively). Except for Ile217, Trp218, and Phe215 residues 245 that appear to exert unfavorable influence in terms of Bt-Val4 246 binding, the remaining PR3 residues promote Bt-Val4 binding 247 with the interaction energy not exceeding $-1 \mathrm{kcal} / \mathrm{mol}$. It 248 should be pointed out that excessively repulsive interactions 249 associated with some residues probably arise from the lack of 250 quantum chemical refinement of the binding poses obtained 251 from docking simulations, as empirical force field based 252 methods often employed throughout the docking procedures 253 tend to introduce shortened intermolecular contacts. ${ }^{28}$ The 254 location of the biotin rings into the S5 binding site prevents 255 recognition of all these compounds by extravidin by Western 256 blotting (WB) under nondenaturating/reducing conditions 257 (not shown).

258 Stability of Bt-VYDnV $\left(\mathrm{O}-\mathrm{C}_{6} \mathrm{H}_{4}-4-\mathrm{Cl}\right)_{2}(11)$ in a Bio259 logical Environment. We then tested the properties of $\mathbf{1 1}$ in 260 sputa from patients with cystic fibrosis (CF) and measured 261 humPR3 activities of sputum samples before and after
Table 4. MP2/6-31+G(d) Interaction Energy ${ }^{a}$ between Amino Acid Residues Representing humPR3 or macPR3 Binding Site and Bt-Val4 Fragment of 11

\begin{tabular}{lcrc} 
& & \multicolumn{2}{c}{ binding energy } \\
\cline { 3 - 4 } \multicolumn{1}{c}{ humPR3 residues } & substituted macPR3 residues & humPR3 & macPR3 \\
Lys99 & & -16.6 & -10.0 \\
Phe165 & Leu & -0.3 & -0.4 \\
Phe166 & Leu & -3.8 & -0.8 \\
Cys168-Cys182 & & -0.8 & -1.2 \\
Asn98-Arg177-Asn180 & & -0.8 & 0.3 \\
Pro178 & Thr & 0.1 & 0.2 \\
Phe192 & & -0.1 & 0.0 \\
Phe215 & & 5.5 & 24.2 \\
Val216 & & -1.6 & -2.6 \\
Ile217 & & 12.3 & 15.4 \\
Trp218 & Arg & 7.6 & 6.4 \\
Gly219 & Glu & -0.3 & -3.3 \\
Phe224 & & -0.6 & -0.9 \\
Pro225 & & -0.6 & -0.7 \\
Phe227 & & -0.8 & -1.6 \\
${ }^{a}$ In units of kcal/mol. & & & \\
\hline
\end{tabular}

incubation with 11 (5-10 nM final). A $1 \mathrm{nM}$ humPR3 262 concentration was estimated in these samples by comparison 263 with the rate of hydrolysis of the ABZ-VADnVADYQ-EDDnp 264 substrate. Cleavage of the humPR3 substrate was totally 265 inhibited after incubation for $20 \mathrm{~min}$ at $37^{\circ} \mathrm{C}$ with $\mathbf{1 1}$ (Figure 266 

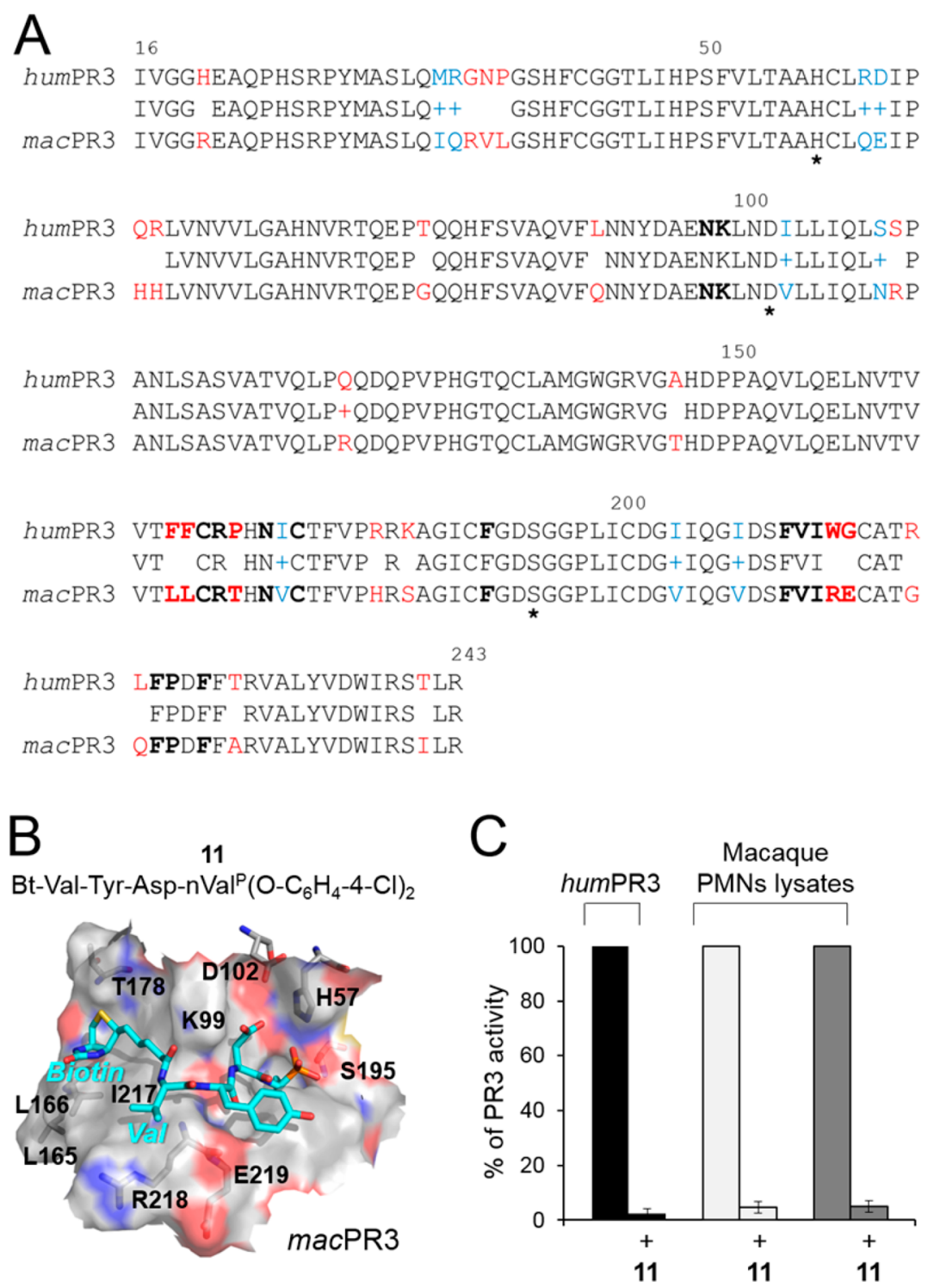

Figure 4. Inhibition of macPR3 by inhibitor 11. (A) Human and macaque sequence alignment. The sequences of humPR3 (1FUJ.pdb) ${ }^{12}$ and macPR3 (Macaca fascicularis, GenPept: XP_005587394.1) were aligned using Protein BLAST with default parameters. Similar amino acid residues are indicated in blue and remaining substitutions are in red. Active center residues are indicated by asterisk. The residues included in quantum chemical calculations are indicated in bold. The sequence numbering according 1FUJ.pdb file. Sequence alignment of humPR3 and macPR3 show 190/221 (86\%) identical positions, 200/221 (90\%) positives, and no gaps. (B) Proposed putative model of 11 in macPR3 active center. (C) Inhibition of PR3 by 11 in macaque neutrophil lysates. The volume of lysates was adjusted to give final concentrations of PR3, 1 nM. Diluted samples were incubated with 11 ( $10 \mathrm{nM}$ final) for $20 \mathrm{~min}$ at $37^{\circ} \mathrm{C}$. Inhibition was monitored by measuring the residual activity of PR3 on ABZVADnVADYQ-EDDnp $(20 \mu \mathrm{M})$ as in Korkmaz et al. ${ }^{52}$ Purified humPR3 $(1 \mathrm{nM})$ was used as control. Similar results were found in three independent experiments.

267 3B), while hum NE activity remained unchanged (not shown). 268 Inhibitor 11 was also successfully used to selectively label 269 proteolytically active humPR3 in CF sputum and in a lysate of 270 purified human blood neutrophils (Figure 3C). Additionally, 271 we showed that inhibitor $\mathbf{1 1}$ preserved full inhibitory activity 272 and resisted degradation when it was mixed with CF sputum 273 for $2 \mathrm{~h}$ at $37{ }^{\circ} \mathrm{C}$ as shown by high performance liquid 274 chromatography (HPLC) (Figure 3D).

275 Characterization and Inhibition of Macaque PR3 276 (macPR3) by Phosphonate Inhibitors in Purified Neu277 trophil Lysates. Protein sequences alignment of humPR3 and 278 macaque PR3 (Macaca fascicularis) shows that they are $86 \%$ 279 identical, and they differ by only 28 residues. Their substrate 280 binding site is very similar and critical residues Lys99, Arg143, and Ile217 that confer high selectivity to humPR3 are conserved 281 in macPR3 (Figure 4A,B). We thus hypothesized that, unlike $282 \mathrm{f} 4$ PR3 homologues in rodents, macPR3 will be efficiently 283 inhibited by peptide-based phosphonate inhibitors designed 284 for humPR3. All phosphonate inhibitors of humPR3 reported 285 above were able to inhibit macPR3. As observed for humPR3, 286 biotinylated inhibitors were more efficient than acylated 287 inhibitors at inhibiting macPR3 (1, Ac-PYDA ${ }^{\mathrm{P}}\left(\mathrm{O}-\mathrm{C}_{6} \mathrm{H}_{4}-4-288\right.$ $\mathrm{Cl})_{2}, k_{\text {obs }} / I=55 \pm 4 \mathrm{M}^{-1} \mathrm{~s}^{-1} ; 2$, Bt-PYDA ${ }^{\mathrm{P}}\left(\mathrm{O}-\mathrm{C}_{6} \mathrm{H}_{4}-4-\mathrm{Cl}\right)_{2}, 289$ $k_{\text {obs }} / I=1985 \pm 215 \mathrm{M}^{-1} \mathrm{~s}^{-1} ; \mathbf{1 1}, \mathrm{Bt}-\mathrm{VYDA}^{\mathrm{P}}\left(\mathrm{O}-\mathrm{C}_{6} \mathrm{H}_{4}-4-\mathrm{Cl}\right)_{2}, 290$ $\left.k_{\text {obs }} / I=36480 \pm 3350 \mathrm{M}^{-1} \mathrm{~s}^{-1}\right)$, but their overall potency was 291 somewhat lesser than that recorded for humPR3 (Table 1). The 292 inhibition of macPR3 with $\mathbf{1 1}$ is shown in Figure 3C. 
$[\mathrm{R}=$

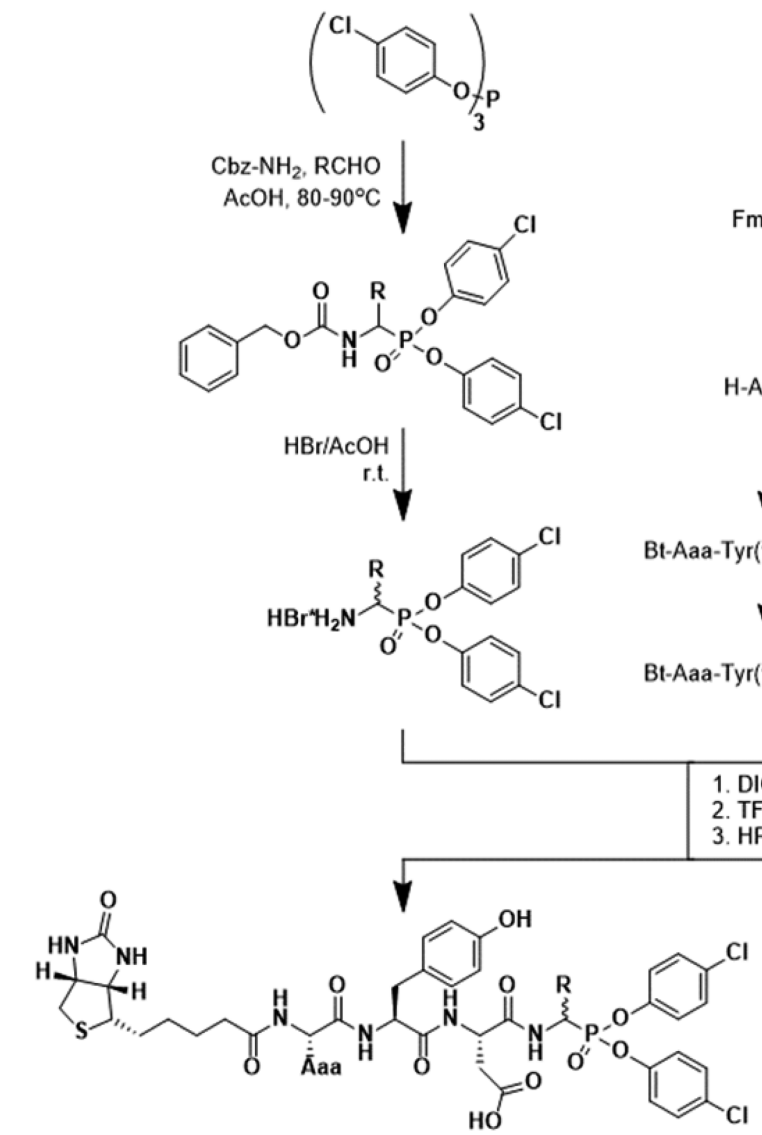

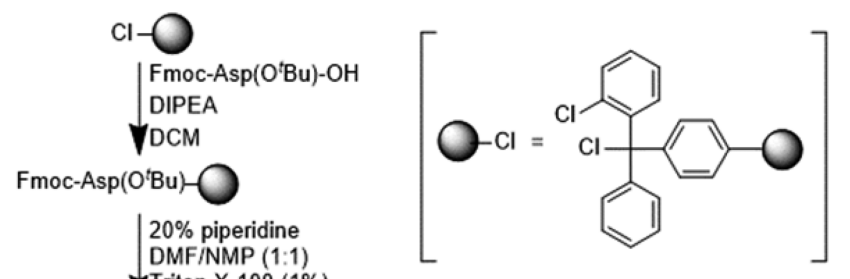

H-Asp(OtBu)-

Fmoc-Tyr('Bu)-OH

$\mathrm{DIC} / \mathrm{HOBt}$

$\checkmark \mathrm{DMF}$

Fmoc-Tyr('Bu)-Asp(O'Bu)-

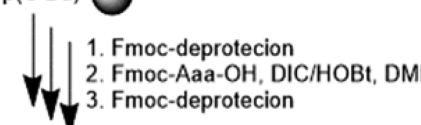

$\left.\begin{array}{rl}A \mathrm{aa}= & \text { Pro } \\ & \text { Val } \\ & \text { Leu } \\ & \text { Ile } \\ & \text { nLeu } \\ & \text { nLeu(OBzl) }\end{array}\right]$

-Aaa-Tyr('Bu)-Asp(O'Bu)-

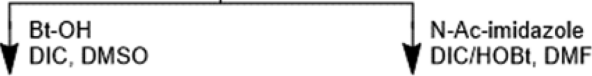

$\left.{ }^{t} \mathrm{Bu}\right)-\mathrm{Asp}\left(\mathrm{O}^{t} \mathrm{Bu}\right) \bigcirc \mathrm{Ac}-\mathrm{Aaa}-\mathrm{Tyr}\left({ }^{\mathrm{B}} \mathrm{B}\right.$
$\downarrow$ TFE/AcOH/hexane $(1: 1: 6, v / v / v)$

DIC, DIPEA, DMF

TFA/PhOH/TIPS/ $\mathrm{H}_{2} \mathrm{O}$

HPLC purification

Figure 5. Scheme showing the synthesis of peptidyl di(chlorophenyl)-phosphonate ester inhibitors.

294 To further examine binding preferences of 11 against human 295 and macPR3 proteases and interaction energy values between $296 \mathrm{Bt}-\mathrm{Val} 4$ fragment of the inhibitor and PR3, binding sites were 297 compared for particular residues representing S5 binding 298 pocket (Table 4). Lys99, the most important residue promoting 299 inhibitor binding of humPR3, seems to exert also the largest 300 influence in terms of the analogous interaction with macPR3. 301 However, the corresponding binding energy value is less 302 significant in the case of macPR3-inhibitor complex compared 303 to interaction with humPR3 ( -10.0 versus $-16.6 \mathrm{kcal} / \mathrm{mol}$; 304 Table 4). Another substantial difference in binding energy 305 values concerns repulsive interaction due to the presence of 306 Phe215 residue. Unfavorable interaction characterizing 307 humPR3-inhibitor complex $(5.5 \mathrm{kcal} / \mathrm{mol})$ amounts to 24.2 $308 \mathrm{kcal} / \mathrm{mol}$ in the corresponding macPR3 Phe215-inhibitor 309 complex (Table 4). The remaining repulsive interactions 310 associated with Ile217 and Trp218 are retained in the case of 311 macPR 3 inhibition despite the substitution of Trp218 by an 312 arginine residue. Interestingly, three out of five substitutions 313 that involve PR3 residues in the vicinity of the Bt-Val4 inhibitor 314 fragment do not seem to modulate binding potency of $\mathbf{1 1}$ 315 against human and macPR3 homologues. The more substantial 316 changes related to residue substitution accompany the change 317 of Phe166 to leucine and Gly219 to glutamate. However, these substitution-induced changes in binding energy cancel each 318 other out, as the interaction energy value increased by $3 \mathrm{kcal} / 319$ mol as a result of the Phe166Leu substitution is decreased by 320 the same extent upon the Gly219Glu substitution. Overall, the 321 differences in inhibitor binding by human and macPR3 appear 322 to arise from decreased attractive interaction with Lys 99 and 323 increased repulsion with Phe 215 residues. Because conforma- 324 tion and spatial placement of these two residues is essentially 325 identical in both complexes, the observed changes in binding 326 energy appear to arise from slightly different positioning of the 327 Bt-Val4 portion of the inhibitor molecule due to substitutions 328 present in the macPR3 S4 and S5 subsites.

\section{DISCUSSION}

Evidence has now accumulated that the neutrophilic serine 331 protease humPR3 acquired specific pathophysiological proper- 332 ties and nonredundant functions in spite of its close 333 resemblance to humNE. ${ }^{5,29}$ Indeed, it slightly differs from the 334 latter by its spatiotemporal localization, ${ }^{30}$ its substrate 335 specificity, and its sensitivity to natural inhibitors, all factors 336 that taken together explain its specific function as an 337 autoantigen in granulomatosis with polyangiitis and its probable 338 involvement in cell apoptosis. ${ }^{6,11}$ Controlling the proteolytic 339 activity of this protease specifically, e.g., by protease inhibitors, 340 
341 is a means to better understand its biological function, but all 342 physiological inhibitors of humPR3 preferentially target 343 humNE. It is only recently that we and others began to 344 synthesize chemical inhibitors that selectively target the 345 humPR3 active site. ${ }^{7}$ The specificity of serine proteases is 346 determined by their substrate binding sites that are located on 347 both sides of the cleaved peptide bond. We used a substrate348 based approach to develop serpin-like irreversible inhibitor 349 (SerpinB1(STDA/R) and azapeptide (azapro-3), a reversible 350 inhibitor that selectively inhibits PR3. ${ }^{31}$ Such inhibitors, 351 however, cannot be used as ABP to visualize active humPR3 352 in biological fluids or in cells and tissues. We recently 353 developed a series of N-terminally biotinylated peptidyl354 diphenyl phosphonate inhibitors that allow the detection of 355 humPR3 at the cell surface and inside cells. ${ }^{18}$ These are 356 transition state analogues, irreversible inhibitors that interact 357 with nonprime subsites of the target serine protease to form 358 "phosphonylated" enzymes. Protease-inhibitor complexes 359 show a remarkable stability due to the similarity of the 360 phosphorus atom with the tetrahedral intermediate formed 361 during peptide bond hydrolysis. Although chemically stable in 362 blood samples, their pharmacological use requires that they 363 interact rapidly with their target protease to be effective at low 364 concentrations. We have further investigated the nonprime 365 specificity of humPR3 to develop more potent di366 (chlorophenyl)-phosphonate ester inhibitors that could be 367 used as molecular probes to control humPR3 activity (Figure 3685 ).

369 We previously showed that the S2/P2 specificity was 370 essential to discriminate between humPR3 and its close 371 homologue humNE. ${ }^{15}$ Lys99 in humPR3 is a key residue to 372 explain the preferential accommodation of negatively charged 373 or polar residues at P2. ${ }^{5,7}$ Thus, selective humPR3 substrates or 374 peptide sequences selectively cleaved by humPR3 all contain a 375 negatively charged or a polar residue at position P2. ${ }^{6}$ 376 SerpinB1(STDA/R) and azapro-3 that selectively inhibit 377 humPR3 contain a negatively charged residue (Asp) at P2 378 position. However, humPR3 may accommodate different 379 residues at $\mathrm{P} 1$ and $\mathrm{P} 4$ as confirmed by molecular modeling 380 studies. The S1 binding pocket of humPR3 is more accessible 381 and spacey than that of hum NE and can accommodate not only 382 the Ala or Abu side chain but also methionine, valine, and $\mathrm{nVal}$, 383 which was shown experimentally and by computational 384 docking. In a recent study using single-residue mutant of 385 humPR3 with Arg at position 217 (PR3I217R), we showed that 386 Ile217 located in the neighborhood of the S4 subsite pocket 387 significantly affects the substrate specificity of humPR3. ${ }^{18}$ The 388 docking models performed in this study using phosphonate 389 inhibitors indicate also that the solvent accessible surface of the 390 S4 subsite is limited by Trp218 and Ile217 on one side. The 391 latter two residues are most likely responsible for the binding 392 preference toward aliphatic side chains at P4 and Lys99, which 393 is located on the opposite side of the S4 subsite, determines 394 cooperation between S2 and S4 via hydrogen bonding. 395 Introduction of a $\mathrm{Val}$ and a $\mathrm{nVal}$ at $\mathrm{P} 4$ and $\mathrm{P} 1$ positions, 396 respectively, in the biotinylated humPR3 inhibitor previously 397 reported, Bt-PYDA ${ }^{\mathrm{P}}\left(\mathrm{O}-\mathrm{C}_{6} \mathrm{H}_{4}-4-\mathrm{Cl}\right)_{2}(2)$, enhanced the $k_{\text {obs }} /[\mathrm{I}]$ 398 value toward humPR3 by $\sim 20$-fold. This was probably because 399 the substitution of Pro4 by Val4 improved the flexibility of the 400 inhibitor, favoring the formation of hydrogen bonds between 401 the $\varepsilon$-amino group of Lys99 and $\mathrm{Bt}$-Val4 amide carbonyl 402 oxygen as well as Asp2 carboxyl group. These hydrogen bond interactions are in agreement with previously described 403 cooperation observed between S2 and S4 subsites. ${ }^{18} 404$

Biotin at the N-terminal of P4 residue in phosphonate 405 inhibitors and peptidyl-pNA substrates displays stabilizing 406 properties. General orientation, size, and hydrophobic character 407 of humPR3 S5 pocket that accommodates N-terminal biotin is 408 similar to that of humNE crystallized in complex with a 409 phosphonate inhibitor bearing a $\mathrm{nLeu}(\mathrm{O}-\mathrm{Bzl})$ moiety at $\mathrm{P} 4$ and 410 called an "exopocket", an extension of the S4 subsite. ${ }^{32}$ The 411 docking models from this study show that the terminal cavity of 412 the humPR3 S5 pocket formed by Phe166, Cys168, and Arg177 413 accommodates the biotin heterocyclic rings, while the hydro- 414 phobic surface of Ile217 interacts with the biotin aliphatic 415 chain. The location of the biotin rings into the S5 binding site 416 prevents recognition of the biotinylated inhibitors by extravidin 417 by WB under nondenaturating conditions (not shown). Only 418 the five-carbon aliphatic chain of biotin participates in the 419 stabilization of the inhibitor within the humPR3 active site as 420 deduced from the observation that a phosphonate inhibitors 421 with a same peptide sequence but bearing only a N-terminal 422 five-carbon aliphatic chain enhanced the inhibition rate as well 423 as whole biotin. ${ }^{18}$ Analysis of the docking models suggests that 424 the substantial impact of N-terminal biotin binding with S5 425 subsite on the overall inhibitory potency might be connected 426 with the limited size of S4 binding site. The main contribution 427 to the binding energy at this position is provided by Lys99, 428 forming the hydrogen bond with the backbone of the inhibitor 429 and stabilizing the biotin moiety in proper orientation. Because 430 of the narrow character of S4 subsite and the presence of 431 Trp218 and Ile217 on the opposite site of Lys99, there is a 432 strong preference for small, hydrophobic residues at P4 433 position. Therefore, the introduction of more sizable side 434 chain such as $\mathrm{nLeu}(\mathrm{O}-\mathrm{Bzl})$ may influence proper stabilization of 435 the compound at P4 subsite, resulting in decreased inhibitory 436 potency.

One of the challenges when designing preclinical studies for 438 PR3 is to select a relevant animal model. We previously showed 439 that PR3 from rodents differs from humPR3 both in terms of 440 substrate specificity, which preclude the use of substrate-derived 441 phosphonate inhibitors and of subcellular distribution because 442 there is no constitutive expression of PR3 at the neutrophil 443 surface of rodent neutrophils. ${ }^{27,33} \mathrm{We}$ therefore used a 444 nonhuman primate model to investigate the substrate 445 specificity of neutrophilic PR3 and its sensitivity to 446 phosphonate inhibitors developed against humPR3. In view of 447 the highly conserved primary amino acid sequence of macPR3 448 implying a very similar specificity as with humPR3, macPR3 449 cleaved the humPR3 substrate at the same site ${ }^{34}$ and this 450 activity was inhibited by all phosphonate inhibitors of humPR3 451 used in this study. WB analysis of the macaque neutrophil 452 lysate using an anti-humPR3 antibody revealed the presence of 453 a single band of $26 \mathrm{kDa}$ in the neutrophil lysate with no 454 glycosylated forms. ${ }^{34}$ A single band of $75 \mathrm{kDa}$ was revealed 455 after the lysate was incubated with human $\alpha 1 \mathrm{PI}$, indicating that 456 macPR3 had formed an irreversible complex with the serpin. In 457 keeping with this observation, the proteolytic activity toward 458 the humPR3 substrate in the lysate was inhibited by $\alpha 1 \mathrm{PI}$ and 459 by the PR3-specific serpinB1(STDA/R) inhibitor ${ }^{35}$ (not 460 shown). The identification of proteolytically active macPR3 in 461 the neutrophil lysate was further confirmed by electrophoresis 462 under nondenaturing/nonreducing conditions using the $\mathrm{ABP} 463$ $\mathrm{Bt}-[\mathrm{PEG}] 66-\mathrm{PYDAP}\left(\mathrm{O}-\mathrm{C}_{6} \mathrm{H}_{6}-4-\mathrm{Cl}\right)_{2}$ and streptavidin-peroxi- 464 dase staining. ${ }^{34}$ We found similar level of active PR3 in lysates 465 
466 of purified human and macaque neutrophils by kinetics and 467 immunobloting assays. The macaque model thus appears as 468 relevant animal model for in vivo studies.

\section{CONCLUSION}

470 Targeting the humPR3 active site by specific inhibitors has 471 become evidence as soon as it has been established that it was 472 not a redundant protease mimicking hum NE and that its 473 proteolytic activity was poorly controlled by physiological 474 inhibitors. We have optimized here the structure of peptidyl 475 phosphonate inhibitors by coupling molecular modeling studies 476 with kinetic analyses, and we obtained molecular probes to 477 follow the fate and further investigate the function of PR3 both 478 in vitro and in vivo. The potency and selectivity of the 479 inhibitors developed here let us suppose that they are suitable 480 therapeutic tools for fighting inflammatory and/or infectious 481 diseases where the role of humPR3 has been clearly identified 482 or even only suspected.

\section{EXPERIMENTAL SECTION}

484 Materials. humNE (EC 3.4.21.37) was obtained from Athens 485 Research and Technology (USA). The fluorescence resonance energy 486 transfer (FRET) substrates ABZ-VADnVADYQ-EDDnp/ABZ487 APEEIMRRQ-EDDnp and chromogenic para-nitroanilide substrates 488 synthesized by Genecust (Dudelange Luxembourg). IGEPAL CA-630 489 (NP40) was purchased from Sigma-Aldrich (St. Louis, MO, USA).

490 Synthesis of Peptidyl-phosphonate Inhibitors. All reagents 491 and solvents were obtained from commercial sources and were used 492 without purification.

493 All final compounds were purified to $>95 \%$ purity HPLC system 494 (Jasco LC System, Jasco, Japan) equipped with Supelco Wide Pore C8 495 column $(8 \mathrm{~mm} \times 250 \mathrm{~mm})$ and ultraviolet-visible (UV-vis, $226 \mathrm{~nm})$ 496 and fluorescent detectors (excitation $320 \mathrm{~nm}$, emission $450 \mathrm{~nm}$ ). A 497 linear gradient from 10 to $90 \%$ of B within 40 min was applied (A, $4980.1 \%$ TFA in water; B, $80 \%$ acetonitrile in A).

499 The nuclear magnetic resonance spectra $\left({ }^{1} \mathrm{H},{ }^{31} \mathrm{P}\right.$ and $\left.{ }^{13} \mathrm{C}\right)$ were 500 recorded on either a Bruker Avance DRX-300 $\left(300.13 \mathrm{MHz}\right.$ for ${ }^{1} \mathrm{H}$ $501 \mathrm{NMR}, 121.50 \mathrm{MHz}$ for ${ }^{31} \mathrm{P}$ NMR), a Bruker Avance $600 \mathrm{MHz}(600.58$ $502 \mathrm{MHz}$ for ${ }^{1} \mathrm{H}$ NMR, $243.10 \mathrm{MHz}$ for ${ }^{31} \mathrm{P} \mathrm{NMR}$, and $101.12 \mathrm{MHz}$ for $503{ }^{13} \mathrm{C}$ NMR) or Bruker AVANCE III $700 \mathrm{MHz}\left(700.67 \mathrm{MHz}\right.$ for ${ }^{1} \mathrm{H}$ 504 NMR) spectrometer. Chemical shifts are reported in parts per million $505(\mathrm{ppm})$ relative to a tetramethylsilane internal standard. Mass spectra 506 were recorded using a Biflex III MALDI TOF mass spectrometer 507 (Bruker, Germany). The cyano-4-hydroxycinnamic acid (CCA) was 508 used as a matrix. High resolution mass spectra (HRMS) were acquired 509 either on a Waters Acquity Ultra Performance LC, LCT Premier XE, 510 or Bruker micrOTOF-Q II mass spectrometer.

511 Cbz-Protected 1-Aminoalkylphosphonate Diaryl Esters (General 512 Procedure). The first step in the synthesis of the phosphonic 513 analogues of $\mathrm{Ala}, \mathrm{nVal}$, and $\mathrm{Abu}$ was the preparation of tri(4514 chlorophenyl)phosphite from 4-chlorophenol and phosphorus tri515 chloride. ${ }^{36}$ Briefly, phosphorus trichloride $(10 \mathrm{mmol})$ was added to 4 516 chlorophenol $(30 \mathrm{mmol})$ dissolved in acetonitrile $(50 \mathrm{~mL})$ and the 517 mixture refluxed for $6 \mathrm{~h}$. The volatile elements were removed in a 518 vacuum, and the resulting crude phosphite, a yellow oil, was used 519 directly in an amidoalkylation reaction. It was mixed with benzyl 520 carbamate $(12 \mathrm{mmol})$ and an appropriate aldehyde: acetaldehyde, 521 butyraldehyde, or propionaldehyde $(12 \mathrm{mmol})$ and refluxed in acetic 522 acid for $3 \mathrm{~h}$ (Oleksyszyn's method ${ }^{37}$ ).

523 Deprotection of Cbz Group (General Procedure). The $\mathrm{Cbz}$ 524 protecting group was removed by incubation with $33 \%$ hydrobromic 525 acid in acetic acid $(2 \mathrm{~h})$. The volatile components were removed under 526 reduced pressure, and the products were crystallized from methanol/ 527 diethyl ether to give target compounds as hydrobromide salts.

528 Benzyl (1-(Bis(4-chlorophenoxy)phosphoryl)ethyl)carbamate (12, $\left.529 \mathrm{Cbz}-\mathrm{Ala}^{P}\left(\mathrm{O}-\mathrm{C}_{6} \mathrm{H}_{4}-4-\mathrm{Cl}\right)_{2}\right)$. 12 was prepared using the general method 530 described above and crystallized from methanol to yield a white solid
(56\%). ${ }^{1} \mathrm{H}$ NMR (300.13 MHz, $\left.\mathrm{CDCl}_{3}-d_{1}, \mathrm{ppm}\right): \delta 7.43-6.97(\mathrm{~m}, 531$ $14 \mathrm{H}), 5.22-5.08(\mathrm{~m}, 2 \mathrm{H}), 4.74-4.37(\mathrm{~m}, 1 \mathrm{H}), 1.56(\mathrm{dd}, J=18.2,7.4532$ $\mathrm{Hz}, 3 \mathrm{H}) .{ }^{31} \mathrm{P}$ NMR $\left(121.50 \mathrm{MHz}, \mathrm{CDCl}_{3}-d_{1}, \mathrm{ppm}\right): \delta 19.56(\mathrm{~s}) .{ }^{13} \mathrm{C} 533$ NMR (101.12 MHz, DMSO- $\left.d_{6}, \mathrm{ppm}\right): \delta 156.16,156.11,151.14,534$ $151.05,150.84,150.74,137.20,134.14,131.91,131.88,128.87,128.46,535$ $128.34,126.15,126.03,121.13,121.09,120.99,119.99,119.73,66.48,536$ 45.30, 43.73, 15.52. HRMS: calcd for $\left(\mathrm{C}_{22} \mathrm{H}_{20} \mathrm{Cl}_{2} \mathrm{NO}_{5} \mathrm{P}\right) \mathrm{H}^{+} 480.0534,537$ found 480.0533 .

538

Benzyl (1-(Bis(4-chlorophenoxy)phosphoryl)propyl)carbamate 539 (13, $\left.\mathrm{Cbz}-\mathrm{Abu}^{P}\left(\mathrm{O}-\mathrm{C}_{6} \mathrm{H}_{4}-4-\mathrm{Cl}\right)_{2}\right) .13$ was prepared using the general 540 method described above and crystallized from methanol to yield a 541 white solid (19\%). ${ }^{1} \mathrm{H}$ NMR (300.13 $\left.\mathrm{MHz}, \mathrm{CDCl}_{3}-d_{1}, \mathrm{ppm}\right): \delta 7.45-542$ $6.99(\mathrm{~m}, 13 \mathrm{H}), 5.14(\mathrm{~d}, J=10.7 \mathrm{~Hz}, 1 \mathrm{H}), 5.24-5.06(\mathrm{~m}, 2 \mathrm{H}), 4.50-543$ $4.33(\mathrm{~m}, 1 \mathrm{H}), 2.20-2.03(\mathrm{~m}, 1 \mathrm{H}), 1.87-1.64(\mathrm{~m}, 1 \mathrm{H}), 1.11(\mathrm{t}, J=7.3544$ $\mathrm{Hz}, 3 \mathrm{H}) .{ }^{31} \mathrm{P}$ NMR $\left(121.50 \mathrm{MHz}, \mathrm{CDCl}_{3}-d_{1}, \mathrm{ppm}\right): \delta 18.31(\mathrm{~s}) .{ }^{13} \mathrm{C} 545$ NMR (101.12 MHz, DMSO- $\left.d_{6}, \mathrm{ppm}\right): \delta 156.85,156.81,149.45,546$ $149.35,149.12$, 149.03, 137.34, 130.35, 130.28, 130.03, 129.86, 129.65, 547 $128.88,128.44,128.32,128.01,122.94,122.90,122.67,122.63,117.44,548$ 66.43, 51.27, 49.72, 22.46, 22.42, 11.16, 11.01. HRMS: calcd for 549 $\left(\mathrm{C}_{23} \mathrm{H}_{22} \mathrm{Cl}_{2} \mathrm{NO}_{5} \mathrm{P}\right) \mathrm{H}^{+}$494.0691, found 494.0699.

Benzyl (1-(Bis(4-chlorophenoxy)phosphoryl)butyl)carbamate 551 $\left(14, \mathrm{Cbz}-n V a P^{P}\left(O-\mathrm{C}_{6} \mathrm{H}_{4}-4-\mathrm{Cl}\right)_{2}\right)$. 14 was prepared using the general 552 method described above and crystallized from methanol to yield a 553 white solid (20\%). ${ }^{1} \mathrm{H}$ NMR (600.58 $\left.\mathrm{MHz}, \mathrm{CDCl}_{3}-d_{1}, \mathrm{ppm}\right): \delta 7.42-554$ $6.68(\mathrm{~m}, 13 \mathrm{H}), 5.24-5.15(\mathrm{~m}, 2 \mathrm{H}), 5.11(\mathrm{~d}, J=12.2 \mathrm{~Hz}, 1 \mathrm{H}), 4.57-555$ $4.44(\mathrm{~m}, 1 \mathrm{H}), 2.07-1.95(\mathrm{~m}, 2 \mathrm{H}), 1.67-1.39(\mathrm{~m}, 2 \mathrm{H}), 1.02-0.93(\mathrm{~m}, 556$ 3H). ${ }^{31} \mathrm{P}$ NMR (243 MHz, CDCl3, ppm): $\delta 18.47$ (s). ${ }^{13} \mathrm{C}$ NMR 557 $\left(101.12 \mathrm{MHz}, \mathrm{DMSO}-d_{6}, \mathrm{ppm}\right): \delta 156.85,156.76,156.71,149.45,558$ $149.35,149.11,149.02,137.32,130.36,130.29,130.05,129.87,129.65,559$ $128.88,128.45,128.34,122.95,122.91,122.67,122.63,117.44,66.44,560$ 49.23, 47.66, 30.63, 19.10, 18.95, 13.68. HRMS: calcd for 561 $\left(\mathrm{C}_{24} \mathrm{H}_{24} \mathrm{Cl}_{2} \mathrm{NO}_{5} \mathrm{P}\right) \mathrm{Na}^{+}$530.0667, found 530.0670 .

Bis(4-chlorophenyl) (1-Aminoethyl)phosphonate Hydrobromide 563 (15, $\left.\mathrm{HBr} \times \mathrm{H}_{2} \mathrm{~N}-\mathrm{Ala}^{P}\left(\mathrm{O}-\mathrm{C}_{6} \mathrm{H}_{4}-4-\mathrm{Cl}\right)_{2}\right) .15$ was prepared using the general 564 method described above and crystallized from diethyl ether to yield a 565 white solid (97\%). ${ }^{1} \mathrm{H}$ NMR (300.13 MHz, DMSO- $\left.d_{6}, \mathrm{ppm}\right): \delta 8.85566$ (s, 3H), 7.57-7.44 (m, 4H), 7.36-7.16 (m, 4H), 4.45-4.24 (m, 1H), 567 1.55 (dd, $J=18.3,7.2 \mathrm{~Hz}, 3 \mathrm{H}) .{ }^{31} \mathrm{P}$ NMR $\left(121.50 \mathrm{MHz}, \mathrm{DMSO}-d_{6}, 568\right.$ ppm): $\delta 16.49$ (s). ${ }^{13} \mathrm{C}$ NMR (101.12 MHz, DMSO- $\left.d_{6}, \mathrm{ppm}\right): \delta 569$ 148.63 , 148.61, 148.53, 148.52, 130.57, 130.54, 130.53, 129.62, 123.02, 570 122.98, 122.94, 117.45, 43.50, 41.93, 13.96, 13.93. HRMS: calcd for 571 $\left(\mathrm{C}_{14} \mathrm{H}_{14} \mathrm{Cl}_{2} \mathrm{NO}_{3} \mathrm{P}\right) \mathrm{H}^{+} 346.0167$, found 346.0172.

Bis(4-chlorophenyl) (1-Aminopropyl)phosphonate Hydrobro- 573 mide (16, $\left.\mathrm{HBr} \times \mathrm{H}_{2} \mathrm{~N}-\mathrm{Abu} \mathrm{P}^{\mathrm{P}}\left(\mathrm{O}-\mathrm{C}_{6} \mathrm{H}_{4}-4-\mathrm{Cl}\right)_{2}\right)$. 16 was prepared using 574 the general method described above and crystallized form diethyl ether 575 to yield a white solid (83\%). ${ }^{1} \mathrm{H}$ NMR $\left(300.13 \mathrm{MHz}\right.$, DMSO- $d_{6}, 576$ ppm): $\delta 8.87(\mathrm{~s}, 2 \mathrm{H}), 7.67-7.13(\mathrm{~m}, 8 \mathrm{H}), 4.21(\mathrm{dt}, J=13.6,6.8 \mathrm{~Hz}, 577$ $1 \mathrm{H}), 2.24-1.74(\mathrm{~m}, 2 \mathrm{H}), 1.11(\mathrm{t}, J=7.4 \mathrm{~Hz}, 3 \mathrm{H}) .{ }^{31} \mathrm{P}$ NMR $(121.50578$ MHz, DMSO- $\left.d_{6}, \mathrm{ppm}\right): \delta 16.50(\mathrm{~s}) .{ }^{13} \mathrm{C}$ NMR (101.12 MHz, DMSO- 579 $\left.d_{6}, \mathrm{ppm}\right): \delta 148.56,148.47,130.58,130.54,123.05,123.01,122.97,580$ 122.93, 48.80, 47.26, 22.01, 21.99, 10.81, 10.72. HRMS: calcd for 581 $\left(\mathrm{C}_{15} \mathrm{H}_{16} \mathrm{Cl}_{2} \mathrm{NO}_{3} \mathrm{P}\right) \mathrm{H}^{+} 360.0318$, found 361.1123 .

Bis(4-chlorophenyl) (1-Aminobutyl)phosphonate hydrobromide 583 (17, $\left.\mathrm{HBr} \times \mathrm{H}_{2} \mathrm{~N}-n \operatorname{nal}^{\mathrm{P}}\left(\mathrm{O}-\mathrm{C}_{6} \mathrm{H}_{4}-4-\mathrm{Cl}\right)_{2}\right)$. 17 was prepared using the 584 general method described above and crystallized from diethyl ether 585 to yield a white solid (89\%). ${ }^{1} \mathrm{H}$ NMR (300.13 MHz, DMSO- $d_{6}, 586$ ppm): $\delta 8.88(\mathrm{~s}, 2 \mathrm{H}), 7.49-7.27(\mathrm{~m}, 8 \mathrm{H}), 4.25(\mathrm{dt}, J=13.9,7.0 \mathrm{~Hz}, 587$ $1 \mathrm{H}), 2.06-1.78(\mathrm{~m}, 2 \mathrm{H}), 1.71-1.46(\mathrm{~m}, 2 \mathrm{H}), 0.90(\mathrm{t}, J=7.3 \mathrm{~Hz}, 3 \mathrm{H}) .588$ ${ }^{31} \mathrm{P}$ NMR (121.50 MHz, DMSO- $\left.d_{6}, \mathrm{ppm}\right): \delta 16.55(\mathrm{~s}) .{ }^{13} \mathrm{C}$ NMR 589 $\left(101.12 \mathrm{MHz}, \mathrm{DMSO}-d_{6}, \mathrm{ppm}\right): \delta 148.59,148.58,148.49,148.48,590$ $130.58,130.53,123.06,123.02,122.96,122.92,47.40,45.85,30.39,591$ 30.36, 19.02, 18.92, 14.06. HRMS: calcd for $\left(\mathrm{C}_{16} \mathrm{H}_{18} \mathrm{Cl}_{2} \mathrm{NO}_{3} \mathrm{P}\right) \mathrm{H}^{+} 592$ 374.0474, found 375.1931 .

593

The peptides were synthesized manually by the solid-phase method 594 using Fmoc chemistry. The following amino acid derivatives were 595 used: Fmoc-Pro, Fmoc-Val, Fmoc-Leu, Fmoc-Ile, Fmoc-nLeu, Fmoc- 596 $\mathrm{nLeu}(\mathrm{O}-\mathrm{Bzl})$, Fmoc-Tyr $(t \mathrm{Bu})$, and Fmoc-Asp $(\mathrm{O} t \mathrm{Bu})$. The protected 597 derivative of the $\mathrm{C}$-terminal amino acid residue, Fmoc-Asp $(\mathrm{O} t \mathrm{Bu})$, was 598 attached to the 2-chlorotrityl resin (substitution of $\mathrm{Cl} 1.46$ mequiv/g) 599 (Calbiochem-Novabiochem AG, Switzerland) in the presence of an 600 
601 equimolar amount of diisopropylethylamine (DIPEA) under anhy602 drous conditions in dichloromethane (DCM) solution. A peptide 603 chain was elongated in consecutive cycles of deprotection $(20 \%$ 604 piperidine in dimethylformamide (DMF) $/ n$-methylpyrrolidone 605 (NMP) (1:1, v/v) with $1 \%$ Triton X-100) and coupling (DIC/ $606 \mathrm{HOBt}$ chemistry; 3 equiv of protected amino acid derivatives were 607 used). A 10-fold molar excess of $\mathrm{N}$-acetylimidazole in DMF was used 608 for acetylation of the N-terminus. Bt-[PEG $]_{2}-\mathrm{Pro}-\mathrm{Tyr}-\mathrm{Asp}-\mathrm{Ala}^{\mathrm{P}}(\mathrm{O}-$ $\left.609 \mathrm{C}_{6} \mathrm{H}_{4}-4-\mathrm{Cl}\right)_{2}$ was synthesized via coupling of the Fmoc- $\mathrm{PEG}_{2}$ to the 610 amino group of terminal Pro residue. The $\mathrm{N}$-terminal biotin group was 611 conjugated using a 5-fold molar excess of biotin and 1,3612 diisopropylcarbidiimide (DIC) as the coupling agent in anhydrous $613 \mathrm{DMSO}$ for $6 \mathrm{~h}$ at $30^{\circ} \mathrm{C}$. The synthesized peptides were cleaved from 614 the resin with TFE/hexane/acetic acid (1:6:1, v/v/v).

615 Fully protected peptides were dissolved in DMF and their carboxyl 616 groups were activated with DIC and coupled with $\mathrm{HBr} \times \mathrm{H}_{2} \mathrm{~N}-\mathrm{Ala}^{\mathrm{P}}(\mathrm{O}-$ $\left.617 \mathrm{C}_{6} \mathrm{H}_{4}-4-\mathrm{Cl}\right)_{2}, \quad \mathrm{HBr} \times \mathrm{H}_{2} \mathrm{~N}-\mathrm{Abu}^{\mathrm{P}}\left(\mathrm{O}-\mathrm{C}_{6} \mathrm{H}_{4}-4-\mathrm{Cl}\right)_{2}$, or $\mathrm{HBr} \times \mathrm{H}_{2} \mathrm{~N}$ $618 \mathrm{nVal}^{\mathrm{P}}\left(\mathrm{O}-\mathrm{C}_{6} \mathrm{H}_{4}-4-\mathrm{Cl}\right)_{2}$ in DMF in the presence of DIPEA. The mixture 619 was stirred for $6 \mathrm{~h}$, and the DMF was removed under reduced 620 pressure. The resulting compounds were suspended in trifluoroacetic 621 acid (TFA)/phenol/triisopropylsilane/ $\mathrm{H}_{2} \mathrm{O}(88: 5: 2: 5, \mathrm{v} / \mathrm{v} / \mathrm{v} / \mathrm{v})$ for 2 $622 \mathrm{~h}$ to remove side chain protecting groups.

623 The crude peptides were purified by HPLC on a Beckman Gold 624 System (Beckman, USA) with an RP Kromasil-100, C8, $5 \mu$ m column $625(8 \mathrm{~mm} \times 250 \mathrm{~mm})$ (Knauer, Germany). The solvent systems were $6260.1 \%$ TFA (A) and 80\% acetonitrile in A (B). Either isocratic 627 conditions or a linear gradient were applied (flow rate $3.0 \mathrm{~mL} / \mathrm{min}$, 628 monitored at $226 \mathrm{~nm}$ ). The purity of the synthesized peptides was 629 verified on RP Kromasil 100, C8, $5 \mu$ m column $(4.6 \mathrm{~mm} \times 250 \mathrm{~mm})$ 630 (Knauer, Germany). The peptides were eluted with a linear gradient of 631 the above solvent system (10\%-90\% B) for $30 \mathrm{~min}$, flow rate $1 \mathrm{~mL} /$ $632 \mathrm{~min}$, monitored at $226 \mathrm{~nm}$. HPLC retention times and ${ }^{1} \mathrm{H}$ NMR 633 spectra of final phosphonate peptide inhibitors are shown in Table 5

Table 5. Calculated and Observed Masses ${ }^{a}$ and HPLC Retention Times of Synthesized Inhibitors 1-11

$\begin{array}{crcc}\text { compd } & \text { calculated mass }(\mathrm{Da}) & \text { found mass }(\mathrm{Da}) & \text { retention time }(\mathrm{min}) \\ \mathbf{1} & 763.56 & 764.67 & 12.36 \\ \mathbf{2} & 947.82 & 948.91 & 13.12 \\ \mathbf{3} & 1266.18 & 1266.23 & 10.05 \\ \mathbf{4} & 949.83 & 951.01 & 12.56 \\ \mathbf{5} & 963.86 & 964.79 & 12.47 \\ \mathbf{6} & 963.86 & 964.92 & 12.51 \\ \mathbf{7} & 963.86 & 964.88 & 12.42 \\ \mathbf{8} & 1055.95 & 1057.08 & 13.57 \\ \mathbf{9} & 961.54 & 962.50 & 13.43 \\ \mathbf{1 0} & 975.87 & 976.95 & 13.20 \\ \mathbf{1 1} & 977.89 & 977.97 & 12.58\end{array}$

${ }^{a}$ The obtained molecular weights represent pseudomolecular ions ( $\mathrm{M}$ $+\mathrm{H})^{+}$.

634 and Supporting Information, respectively. Mass spectrometric analysis 635 of the inhibitors (Table 5) was done on a MALDI MS (a Biflex III 636 MALDI-TOF spectrometer, Bruker Daltonics, Germany) using a CCA 637 matrix.

638 Enzymatic Studies: Free humPR3 and humNE Were Titrated 639 with $\alpha 1 \mathrm{PI}^{38} k_{\text {cat }} / K_{\mathrm{m}}$ determination: The specificity constants $k_{\text {cat }} / K_{\mathrm{m}}$ 640 for peptidyl-pNA substrates were determined under first-order 641 conditions. ${ }^{38}$ The cleavage of the substrates ( $1 \mathrm{mM}$ final) was 642 monitored by measuring the absorbance of liberated pNA at $410 \mathrm{~nm}$ 643 on the spectrophotometer (Versamax microplate reader, Molecular 644 Devices, Sunnyvale, CA, USA). Measurements were carried out at 37 $645{ }^{\circ} \mathrm{C}$ in buffer $50 \mathrm{mM}$ HEPES, $0.75 \mathrm{M} \mathrm{NaCl}, 0.05 \% \mathrm{NP} 40$, pH 7.4. Final 646 protease concentrations were $0.01-1 \mu \mathrm{M}$.

$647 k_{\mathrm{obs}} /[\mathrm{I}]$ determination: The inactivation of proteases by phospho648 nate inhibitors (substrate analogue inhibitors) in the presence of the 649 substrate by competition for the enzyme-binding site was measured by the method of Tian and Tsou. ${ }^{39}$ Product formation in the presence of 650 an irreversible inhibitor approaches an asymptote in this system, as 651 described by $\log \left(\left[\mathrm{P}_{\infty}\right]-[\mathrm{P}]\right)=\log \left[\mathrm{P}_{\infty}\right]-0.43 A[\mathrm{Y}] t$.

- where $\left[\mathrm{P}_{\infty}\right]$ is the concentration of product formed at time 653 approaching infinity, $[\mathrm{P}]$ is the concentration of product at time 654 $t,[\mathrm{Y}]$ is the inhibitor concentration, and $A$ is the apparent 655 inhibition rate constant in the presence of the substrate. $A$ is 656 given by $A=k_{+\mathrm{o}} /\left(1+K^{-1}[\mathrm{~S}]\right)$

- where $k_{+o}$ is the rate constant for association of the inhibitor 658 with the enzyme, $K^{-1}$ is the inverted Michaelis constant, and 659 $[S]$ the substrate concentration. The apparent inhibition rate 660 constant $A$ is the slope of a plot of $\log \left(\left[\mathrm{P}_{\infty}\right]-[\mathrm{P}]\right)$ against $t$, to 661 give the second-order rate constant of inhibition $k_{+0} \cdot 662$

The rates of inhibition of purified humPR3, macPR3 (in purified 663 blood neutrophil lysates), and purified humNE were measured using 664 FRET substrates (ABZ-VADnVADYQ-EDDnp (10 $\mu \mathrm{M}$ final) and 665 ABZ-APEEIMRRQ-EDDnp (10 $\mu \mathrm{M}$ final) in $50 \mathrm{mM}$ HEPES, $0.75 \mathrm{M} 666$ $\mathrm{NaCl}$, and $0.05 \% \mathrm{NP} 40, \mathrm{pH}=7.4$; excitation wavelength, $320 \mathrm{~nm}$; 667 emission wavelength, $420 \mathrm{~nm}$; Spectramax Gemini (Molecular 668 Devices, Sunnyvale, CA, USA). Final protease concentrations were 1669 $\mathrm{nM}$.

$K_{\mathrm{i}}$ and $k_{2}$ determination: We monitored the extent of protease 671 inhibition at several time points for a different inhibitor concentrations 672 [I]. The observed rate constant for inhibition, $k_{\text {obs }}$, at each 673 concentration was determined from the slope of a semilogarithmic 674 plot of inhibition versus time. The $k_{\text {obs }}$ values were replotted against 675 inhibitor concentration and fitted to a hyperbolic equation, $k_{\mathrm{obs}}=676$ $k_{2}[\mathrm{I}] /\left(K_{\mathrm{i}}+[\mathrm{I}]\right)$, to obtain values for $K_{\mathrm{i}}$ and $k_{2}{ }^{40}$

Detection of PR3 in Biological Fluids. CF sputa $(50 \mu \mathrm{g} 678$ proteins) were incubated with 11 ( $50 \mathrm{nM}$ final) for $20 \mathrm{~min}$ at $37^{\circ} \mathrm{C}$ in 679 PBS. The reaction was stopped by adding 1 volume of $2 \times$ SDS 680 reducing buffer and heating at $90{ }^{\circ} \mathrm{C}$ for $5 \mathrm{~min}$. The components of 681 the mixture were separated by SDS-PAGE, 12\% NaDodSO4- 682 polyacrylamide gel electrophoresis under denaturing conditions. 683 They were transferred to a nitrocellulose (Hybond)-ECL (Enhanced 684 Chemiluminescence) membrane at $4{ }^{\circ} \mathrm{C}$.

Extravidin Peroxidase Detection. Free sites on the membrane were 686 blocked with 3\% bovine serum albumin (BSA) in 0.1\% Tween in PBS 687 for $90 \mathrm{~min}$ at room temperature (RT). Membranes were then given 688 two quick washes with PBS-Tween $0.1 \%$ and incubated for $2 \mathrm{~h}$ at RT 689 with extravidin horseradish peroxidase (HRP) (Sigma-Aldrich) 690 (diluted $1 / 4000$ in 3\% BSA in PBS-Tween 0.1\%). The extravidin- 691 HRP treated membrane was washed $(3 \times 10 \mathrm{~min})$ with PBS-Tween 692 $1 \%$ and then incubated with HRP substrate for 3 min. Reactive bands 693 were identified by chemiluminescence (ECL Kit).

Immunodetection. Free sites on the membranes were blocked by 695 incubation with 5\% nonfat dried milk in PBS-0.1\% Tween for 90 min 696 at RT. They were washed twice with PBS-Tween $0.1 \%$ and incubated 697 overnight with a rabbit primary anti-PR3 antibody (1:700, EPR6277 698 Abcam), followed by a goat antirabbit IgG secondary antibody 699 (1:7000, A9169 Sigma). These membranes were then washed and 700 processed as above.

Purification and Lysis of $\boldsymbol{M}$. fascicularis Neutrophils. Female 702 cynomolgus monkeys (Macaca fascicularis) (approximately 3 years old 703 and weighing 4-5 kg) were obtained from a commercial supplier. All 704 animal experiments and procedures were approved by the local animal 705 experimentation ethics committee (Comité d'éthique Val de Loire 706 (APAFIS no. 2982-20151105293399v6)). Five $\mathrm{mL}$ of peripheral blood 707 samples were collected in lithium-heparin tubes from a femoral vein. 708 Animals were kept under spontaneous ventilation during anesthesia 709 with ketamine $(10 \mathrm{mg} / \mathrm{kg})$. The monitoring included pulse-oximetry 710 and heart rate recording. Intravenous access was secured with a $22 \mathrm{G} 711$ canula on the legs. Anticoagulated whole blood was layered onto Ficoll 712 density gradient and centrifuged. The purified neutrophils $(>98 \%)$ in 713 suspension was treated with $\mathrm{H}_{2} \mathrm{O}$ for $30 \mathrm{~s}$ to lyse red blood cells. The 714 neutrophils were then lysed in Hepes $50 \mathrm{mM}, \mathrm{NaCl} 0.15 \mathrm{M}$, NP40 715 $0.5 \%, \mathrm{pH} 7.4$, and the supernatant was collected and stored at $-80{ }^{\circ} \mathrm{C} .716$

Chromatographic Procedures and Peptide Analysis. Inhibitor 717 $11(75 \mu \mathrm{M}$ final) was incubated with the cell free supernatants of sputa 718 
719 from CF patients at $37{ }^{\circ} \mathrm{C}$ for $2 \mathrm{~h}$ in PBS. FRET substrate ABZ720 VADnVADYQ-EDDnp ${ }^{15}(20 \mu \mathrm{M}$ final) was incubated with hum $\mathrm{R} 3$ 721 and macaque neutrophil lysate supernatant $(10-500 \mathrm{nM})$ at $37{ }^{\circ} \mathrm{C}$ in $72250 \mathrm{mM}$ HEPES, $0.75 \mathrm{M} \mathrm{NaCl}$, and $0.05 \% \mathrm{NP} 40, \mathrm{pH}=7.4$. The 723 proteins were precipitated with absolute ethanol (4 volumes). The 724 supernatant containing the peptides were dried under vacuum and 725 dissolved in $200 \mu \mathrm{L}$ of $0.01 \%$ trifluoroacetic acid $(\mathrm{v} / \mathrm{v})$, then 726 fractionated by Agilent Technology 1200 series HPLC system (Agilent 727 Technology, CA, USA) on a C18 column $(2.1 \mathrm{~mm} \times 30 \mathrm{~mm}$, Merck 728 Millipore) at a flow rate of $0.3 \mathrm{~mL} / \mathrm{min}$ with a linear gradient $(0-90 \%$, $729 \mathrm{v} / \mathrm{v}$ ) of acetonitrile in $0.01 \%$ trifluoroacetic acid over $40 \mathrm{~min}$. Eluted 730 peaks were monitored at $220 \mathrm{~nm}$.

731 Molecular Modeling. Molecular docking was performed in order 732 to explain interactions of Ac-PYDA ${ }^{\mathrm{P}}\left(\mathrm{O}-\mathrm{C}_{6} \mathrm{H}_{4}-4-\mathrm{Cl}\right)_{2}$ (1), Bt$733 \mathrm{PYDA}^{\mathrm{P}}\left(\mathrm{O}-\mathrm{C}_{6} \mathrm{H}_{4}-4-\mathrm{Cl}\right)_{2}(2)$, Bt-nLeu $(\mathrm{O}-\mathrm{Bzl}) \mathrm{YDA}^{\mathrm{P}}\left(\mathrm{O}-\mathrm{C}_{6} \mathrm{H}_{4}-4-\mathrm{Cl}\right)_{2}$ $734(8)$, and $\mathrm{Bt}-\mathrm{VYDnV}{ }^{\mathrm{P}}\left(\mathrm{O}-\mathrm{C}_{6} \mathrm{H}_{4}-4-\mathrm{Cl}\right)_{2}$ (11) with humPR3 and 735 macPR3. As a receptor, the crystal structure of humPR3 (1FUJ.pdb) ${ }^{12}$ 736 was selected. The same structure was used as a template for macPR3 737 3D model obtained by means of automated homology modeling 738 server, SWISS-MODEL. ${ }^{41}$ For the docking studies, inhibitor molecules 739 were used as a peptidyl phosphonic acids $\left[\mathrm{Ac}-\mathrm{PYDA}^{\mathrm{P}}(\mathrm{OH})_{2}\right.$, Bt$740 \operatorname{PYDA}^{\mathrm{P}}(\mathrm{OH})_{2}, \mathrm{Bt}-\mathrm{VYDnV}^{\mathrm{P}}(\mathrm{OH})_{2}$, and $\left.\mathrm{Bt}-\mathrm{nLeu}(\mathrm{O}-\mathrm{Bzl}) \mathrm{YDA}^{\mathrm{P}}(\mathrm{OH})_{2}\right]$ 741 instead of di(chlorophenyl)-phosphonate esters, as this is the form 742 present in the "aged" protein-inhibitor complex. The ligand models 743 were optimized using the MM2 force field (as implemented in 744 ChemBio3D 12.0), ${ }^{42}$ while the atom types and protonation of all 745 structures were set using SPORES. ${ }^{43}$ The docking was carried out 746 using the Protein-Ligand ANT System (PLANTS v. 1.2) with 747 PLANTS $_{\text {CHEMPLP }}$ scoring function. ${ }^{44-46}$ The protein molecules were 748 treated as fixed with the binding site center defined at a carbonyl 749 oxygen of Ser 214 and the binding site radius of $15 \AA$. The distance 750 constraints were set up to increase the preference of interaction 751 between (a) inhibitor phosphorus atom and the hydroxide oxygen of 752 protease Ser195 (distance range was defined between 2.2 and $4.0 \AA$ ), 753 (b) the terminal carbon of $\mathrm{Ala} / \mathrm{nVal}$ side chain of ligand $\mathrm{P} 1$ position 754 and enzyme S1 binding pocket set at $\gamma$-carbon of Ile190 (distance 755 range: $5.5-6.5 \AA$ for Ala and 2.2-5.0 $\AA$ for nVal), (c) Asp $\gamma$-carbon of 756 the inhibitor (P2 position) and PR3 $\varepsilon$-amine nitrogen of Lys99 757 (distance range 2.0-5.0 $\AA$ ), and (d) ligand P3-P4 amide bond 758 nitrogen and Val216 carbonyl oxygen of the receptor (distance range 759 2.0-5.0 ̊). The lowest energy binding poses obtained from docking 760 simulations were then employed in quantum chemical calculations of 761 interaction energy between PR3 amino acid residues and Bt-Val4 762 fragment of inhibitor to explain the differences in activity of $\mathbf{1 1}$ toward 763 human and macaque enzyme. humPR3 or macPR3 binding site was 764 represented by all amino acid residues within $6 \AA$ of inhibitor fragment 765 considered herein. Because of the presence of disulfide bridge in the 766 vicinity of inhibitor molecule, covalently linked Cys 168 and Cys 182 767 residues were included as a single monomer. Arg177 was found to be 768 hydrogen-bonded to Asn98 and Asn 180 residues. To avoid disrupting 769 the hydrogen bonding network, these three residues were also 770 considered as a monomer. The remaining 15 PR3 residues were 771 included separately. The dangling bonds resulting from cutting the 772 residues out of the protein scaffold were saturated with hydrogen 773 atoms. PR3-inhibitor binding energy was calculated in a pairwise 774 manner at the second-order Møller-Plesset level of theory (MP2) 775 using $6-31+\mathrm{G}(\mathrm{d})$ basis set $^{47-49}$ and counterpoise correction to 776 eliminate basis set superposition error. ${ }^{50}$ Quantum chemical 777 calculations were performed in Gaussian09 program. $^{51}$

\section{ASSOCIATED CONTENT}

\section{S Supporting Information}

780 The Supporting Information is available free of charge on the 781 ACS Publications website at DOI: 10.1021/acs.jmed782 chem. $7 \mathrm{~b} 01416$.

783 Spectroscopic data of synthesized inhibitors; supporting 784 Information includes ${ }^{1} \mathrm{H}$ NMR spectra together with 785 SMILES for compounds 1-11 (PDF)
Docking poses for 1, 2, 8, and $\mathbf{1 1}$ with humPR3 and 11786 with macR3 (ZIP)

Compound data (CSV)

AUTHOR INFORMATION 789 Corresponding Author

*Phone: (0033) 2473662 53. E-mail: brice.korkmaz@inserm. 791 fr.

\section{ORCID $\odot$}

Edyta Dyguda-Kazimierowicz: 0000-0002-9154-5107

Adam Lesner: 0000-0001-8335-3431

Brice Korkmaz: 0000-0002-5159-8706

Carla Guarino and Natalia Gruba contributed equally to this 798 work. Brice Korkmaz supervised the work. Brice Korkmaz and 799 Adam Lesner participated in the research design. Carla 800 Guarino, Natalia Gruba, Renata Grzywa, Edyta Dyguda- 801 Kazimierowicz, Yveline Hamon, Monika Legowska, Marcin 802 Skoreński, Sandrine Dallet-Choisy, Sylvain Marchand-Adam, 803 and Christine Kellenberger conducted the experiments. Brice 804 Korkmaz, Adam Lesner, Francis Gauthier, Marcin Sienczyk, 805 and Dieter E. Jenne performed data analyses. Brice Korkmaz 806 wrote the manuscript. All authors contributed to the writing 807 and revision processes of the manuscript.

Notes

808

The authors declare no competing financial interest.

\section{ACKNOWLEDGMENTS}

810

This work was supported by the Ministère de l'Enseignement 812 Supérieur et de la Recherche, the Région Centre and the Fonds 813 Européen de Développement Régional (Project INFINHI), 814 and the Polish Ministry of Science and Higher Education 815 granted to M.W. (project no. IP2012 0596 72). B.K. 816 acknowledges the Association Vaincre La Mucoviscidose 817 (AVLM) and the Alexandre von Humboldt Foundation. M.S. 818 and R.G. are grateful for support to Wroclaw University of 819 Science and Technology (statute funds 10401/0194/17). We 820 thank Lise Vanderlynden (INSERM U-1100) and Heike 821 Reimann (Comprehensive Pneumology Center, Institute of 822 Lung Biology and Disease, iLBD) for technical assistance. 823

\section{ABBREVIATIONS USED}

824

$\mathrm{ABP}$, activity-based probe; $\alpha 1 \mathrm{PI}$, alpha-1-proteinase inhibitor; 825 ABZ, ortho-aminobenzoic acid; Bt, biotin; HPLC, high 826 performance liquid chromatography; CG, cathepsin G; CF, 827 cystic fibrosis; EDDnp, $\mathrm{N}$-(2.4-dinitrophenyl)ethylenediamine; 828 FRET, fluorescence resonance energy transfer; GPA, gran- 829 ulomatosis with polyangiitis; hum, human; NE, neutrophil 830 elastase; NSP, neutrophil serine protease; PBS, phosphate- 831 buffered saline; PEG, polyethlene glycol; PMN, polymorpho- 832 nuclear neutrophil; pNA, para-nitroaniline; PR3, proteinase 3; 833 WB, Western blot

(1) Pham, C. T. Neutrophil serine proteases: specific regulators of 836 inflammation. Nat. Rev. Immunol. 2006, 6, 541-550.

(2) Pham, C. T. Neutrophil serine proteases fine-tune the 838 inflammatory response. Int. J. Biochem. Cell Biol. 2008, 40, 1317-1333. 839 (3) Perera, N. C.; Wiesmuller, K. H.; Larsen, M. T.; Schacher, B.; 840 Eickholz, P.; Borregaard, N.; Jenne, D. E. NSP4 is stored in azurophil 841 granules and released by activated neutrophils as active endoprotease 842 with restricted specificity. J. Immunol. 2013, 191, 2700-2707. 
844 (4) Owen, C. A. Roles for proteinases in the pathogenesis of chronic 845 obstructive pulmonary disease. Int. J. Chronic Obstruct. Pulm. Dis. 2008, $8463,253-268$.

847 (5) Korkmaz, B.; Horwitz, M.; Jenne, D. E.; Gauthier, F. Neutrophil 848 elastase, proteinase 3 and cathepsin $\mathrm{G}$ as therapeutic targets in human 849 diseases. Pharmacol. Rev. 2010, 62, 726-759.

850 (6) Korkmaz, B.; Lesner, A.; Guarino, C.; Wysocka, M.; Kellenberger, 851 C.; Watier, H.; Specks, U.; Gauthier, F.; Jenne, D. E. Inhibitors and 852 antibody fragments as potential anti-inflammatory therapeutics 853 targeting neutrophil proteinase 3 in human disease. Pharmacol. Rev. 854 2016, 68, 603-630.

855 (7) Korkmaz, B.; Kellenberger, C.; Viaud-Massuard, M. C.; Gauthier, 856 F. Selective inhibitors of human neutrophil proteinase 3. Curr. Pharm. 857 Des. 2013, 19, 966-976.

858 (8) Jenne, D. E.; Tschopp, J.; Ludemann, J.; Utecht, B.; Gross, W. L. 859 Wegener's autoantigen decoded. Nature 1990, 346, 520.

860 (9) Kallenberg, C. G. Pathogenesis of PR3-ANCA associated 861 vasculitis. J. Autoimmun. 2008, 30, 29-36.

862 (10) Kallenberg, C. G.; Heeringa, P.; Stegeman, C. A. Mechanisms of 863 Disease: pathogenesis and treatment of ANCA-associated vasculitides. 864 Nat. Clin. Pract. Rheumatol. 2006, 2, 661-670.

865 (11) Loison, F.; Zhu, H.; Karatepe, K.; Kasorn, A.; Liu, P.; Ye, K.; 866 Zhou, J.; Cao, S.; Gong, H.; Jenne, D. E.; Remold-O’Donnell, E.; Xu, 867 Y.; Luo, H. R. Proteinase 3-dependent caspase-3 cleavage modulates 868 neutrophil death and inflammation. J. Clin. Invest. 2014, 124, 44458694458.

870 (12) Fujinaga, M.; Chernaia, M. M.; Halenbeck, R.; Koths, K.; James, $871 \mathrm{M}$. N. The crystal structure of PR3, a neutrophil serine proteinase 872 antigen of wegener's granulomatosis antibodies. J. Mol. Biol. 1996, 261, 873 267-278.

874 (13) Korkmaz, B.; Moreau, T.; Gauthier, F. Neutrophil elastase, 875 proteinase 3 and cathepsin G: physicochemical properties, activity and 876 physiopathological functions. Biochimie 2008, 90, 227-242.

877 (14) Hedstrom, L. Serine protease mechanism and specificity. Chem. 878 Rev. 2002, 102, 4501-4523.

879 (15) Korkmaz, B.; Hajjar, E.; Kalupov, T.; Reuter, N.; Brillard880 Bourdet, M.; Moreau, T.; Juliano, L.; Gauthier, F. Influence of charge 881 distribution at the active site surface on the substrate specificity of 882 human neutrophil protease 3 and elastase. A kinetic and molecular 883 modeling analysis. J. Biol. Chem. 2007, 282, 1989-1897.

884 (16) Bode, W.; Meyer, E., Jr.; Powers, J. C. Human leukocyte and 885 porcine pancreatic elastase: $\mathrm{x}$-ray crystal structures, mechanism, 886 substrate specificity, and mechanism-based inhibitors. Biochemistry 887 1989, 28, 1951-1963.

888 (17) Bode, W.; Wei, A. Z.; Huber, R.; Meyer, E.; Travis, J.; 889 Neumann, S. X-ray crystal structure of the complex of human 890 leukocyte elastase (PMN elastase) and the third domain of the turkey 891 ovomucoid inhibitor. ЕMBO. J. 1986, 5, 2453-2458.

892 (18) Guarino, C.; Legowska, M.; Epinette, C.; Kellenberger, C.; 893 Dallet-Choisy, S.; Sienczyk, M.; Gabant, G.; Cadene, M.; Zoidakis, J.; 894 Vlahou, A.; Wysocka, M.; Marchand-Adam, S.; Jenne, D. E.; Lesner, 895 A.; Gauthier, F.; Korkmaz, B. New selective peptidyl di(chlorophenyl) 896 phosphonate esters for visualizing and blocking neutrophil proteinase 8973 in human diseases. J. Biol. Chem. 2014, 289, 31777-31791.

898 (19) Oleksyszyn, J.; Powers, J. C. Irreversible inhibition of serine 899 proteases by peptide derivatives of (alpha-aminoalkyl)phosphonate 900 diphenyl esters. Biochemistry 1991, 30, 485-493.

901 (20) Powers, J. C.; Asgian, J. L.; Ekici, O. D.; James, K. E. Irreversible 902 inhibitors of serine, cysteine, and threonine proteases. Chem. Rev. 903 2002, 102, 4639-4750.

904 (21) Mucha, A.; Kafarski, P.; Berlicki, L. Remarkable potential of the 905 alpha-aminophosphonate/phosphinate structural motif in medicinal 906 chemistry. J. Med. Chem. 2011, 54, 5955-5980.

907 (22) Sienczyk, M.; Oleksyszyn, J. Irreversible inhibition of serine 908 proteases - design and in vivo activity of diaryl alpha-amino909 phosphonate derivatives. Curr. Med. Chem. 2009, 16, 1673-1687.

910 (23) Grzywa, R.; Sienczyk, M. Phosphonic esters and their 911 application of protease control. Curr. Pharm. Des. 2013, 19, 11549121178 .
(24) Kasperkiewicz, P.; Poreba, M.; Snipas, S. J.; Parker, H.; 913 Winterbourn, C. C.; Salvesen, G. S.; Drag, M. Design of ultrasensitive 914 probes for human neutrophil elastase through hybrid combinatorial 915 substrate library profiling. Proc. Natl. Acad. Sci. U. S. A. 2014, 111, 916 $2518-2523$.

917

(25) Kam, C. M.; Kerrigan, J. E.; Dolman, K. M.; Goldschmeding, R; 918 Von dem Borne, A. E.; Powers, J. C. Substrate and inhibitor studies on 919 proteinase 3. FEBS Lett. 1992, 297, 119-123.

920

(26) Grzywa, R.; Burchacka, E.; Lecka, M.; Winiarski, L.; Walczak, 921 M.; Lupicka-Slowik, A.; Wysocka, M.; Burster, T.; Bobrek, K.; 922 Csencsits-Smith, K.; Lesner, A.; Sienczyk, M. Synthesis of Novel 923 phosphonic-type activity-based probes for neutrophil serine proteases 924 and their application in spleen lysates of different organisms. 925 ChemBioChem 2014, 15, 2605-2612.

926

(27) Korkmaz, B.; Jenne, D. E.; Gauthier, F. Relevance of the mouse 927 model as a therapeutic approach for neutrophil proteinase 3-associated 928 human diseases. Int. Immunopharmacol. 2013, 17, 1198-1205. 929

(28) Grzywa, R.; Dyguda-Kazimierowicz, E.; Sienczyk, M.; Feliks, M.; 930 Sokalski, W. A.; Oleksyszyn, J. The molecular basis of urokinase 931 inhibition: from the nonempirical analysis of intermolecular 932 interactions to the prediction of binding affinity. J. Mol. Model. 933 2007, 13, 677-683.

(29) Korkmaz, B.; Poutrain, P.; Hazouard, E.; de Monte, M.; Attucci, 935 S.; Gauthier, F. L. Competition between elastase and related proteases 936 from human neutrophil for binding to alpha1-protease inhibitor. Am. J. 937 Respir. Cell Mol. Biol. 2005, 32, 553-559.

938

(30) Kasperkiewicz, P.; Altman, Y.; D’Angelo, M.; Salvesen, G. S.; 939 Drag, M. Toolbox of fluorescent probes for parallel imaging reveals 940 uneven location of serine proteases in neutrophils. J. Am. Chem. Soc. 941 2017, 139, 10115-10125.

(31) Epinette, C.; Croix, C.; Jaquillard, L.; Marchand-Adam, S.; Kellenberger, C.; Lalmanach, G.; Cadene, M.; Viaud-Massuard, M. C.; 944 Gauthier, F.; Korkmaz, B. A selective reversible azapeptide inhibitor of 945 human neutrophil proteinase 3 derived from a high affinity FRET 946 substrate. Biochem. Pharmacol. 2012, 83, 788-796. 947

(32) Lechtenberg, B. C.; Kasperkiewicz, P.; Robinson, H.; Drag, M.; 948 Riedl, S. J. The elastase-PK101 structure: mechanism of an 949 ultrasensitive activity-based probe revealed. ACS Chem. Biol. 2015, 950 10, 945-951.

(33) Kalupov, T.; Brillard-Bourdet, M.; Dade, S.; Serrano, H.; 952 Wartelle, J.; Guyot, N.; Juliano, L.; Moreau, T.; Belaaouaj, A.; 953 Gauthier, F. Structural characterization of mouse neutrophil serine 954 proteases and identification of their substrate specificities: relevance to 955 mouse models of human inflammatory diseases. J. Biol. Chem. 2009, 956 284, 34084-34091.

957

(34) Guarino, C.; Hamon, Y.; Croix, C.; Lamort, A. S.; Dallet-Choisy, 958 S.; Marchand-Adam, S.; Lesner, A.; Baranek, T.; Viaud-Massuard, M. 959 C.; Lauritzen, C.; Pedersen, J.; Heuze-Vourc'h, N.; Si-Tahar, M.; 960 Firatli, E.; Jenne, D. E.; Gauthier, F.; Horwitz, M. S.; Borregaard, N.; 961 Korkmaz, B. Prolonged pharmacological inhibition of cathepsin C 962 results in elimination of neutrophil serine proteases. Biochem. 963 Pharmacol. 2017, 131, 52-67.

(35) Jegot, G.; Derache, C.; Castella, S.; Lahouassa, H.; Pitois, E.; 965 Jourdan, M. L.; Remold-O’Donnell, E.; Kellenberger, C.; Gauthier, F.; 966 Korkmaz, B. A substrate-based approach to convert serpinB1 into a 967 specific inhibitor of proteinase 3, the Wegener's granulomatosis 968 autoantigen. FASEB J. 2011, 25, 3019-3031.

969

(36) Sienczyk, M.; Oleksyszyn, J. Inhibition of trypsin and urokinase 970 by cbz-amino(4-guanidinophenyl)methanephosphonate aromatic ester 971 derivatives: the influence of the ester group on their biological activity. 972 Bioorg. Med. Chem. Lett. 2006, 16, 2886-2890.

973

(37) Oleksyszyn, J.; Powers, J. C. Irreversible inhibition of serine 974 proteases by peptidyl derivatives of alpha-aminoalkylphosphonate 975 diphenyl esters. Biochem. Biophys. Res. Commun. 1989, 161, 143-149. 976 (38) Korkmaz, B.; Attucci, S.; Hazouard, E.; Ferrandiere, M.; 977 Jourdan, M. L.; Brillard-Bourdet, M.; Juliano, L.; Gauthier, F. 978 Discriminating between the activities of human neutrophil elastase 979 and proteinase 3 using serpin-derived fluorogenic substrates. J. Biol. 980 Chem. 2002, 277, 39074-39081. 
982 (39) Tian, W. X.; Tsou, C. L. Determination of the rate constant of 983 enzyme modification by measuring the substrate reaction in the 984 presence of the modifier. Biochemistry 1982, 21, 1028-1032.

985 (40) Singh, J.; Petter, R. C.; Baillie, T. A.; Whitty, A. The resurgence 986 of covalent drugs. Nat. Rev. Drug Discovery 2011, 10, 307-317.

987 (41) Biasini, M.; Bienert, S.; Waterhouse, A.; Arnold, K.; Studer, G.; 988 Schmidt, T.; Kiefer, F.; Cassarino, T. G.; Bertoni, M.; Bordoli, L.; 989 Schwede, T. SWISS-MODEL: modelling protein tertiary and 990 quaternary structure using evolutionary information. Nucleic Acids 991 Res. 2014, 42, W252-W258.

992 (42) Burkert, U.; Allinger, N. L. Molecular Mechanics; ACS 993 Monograph 177; American Chemical Society: Washington, DC, 1982. 994 (43) ten Brink, T.; Exner, T. E. pK(a) based protonation states and 995 microspecies for protein-ligand docking. J. Comput.-Aided Mol. Des. 996 2010, 24, 935-942.

997 (44) Korb, O.; Stutzle, T.; Exner, T. E. Empirical scoring functions 998 for advanced protein-ligand docking with plants. J. Chem. Inf. Model. 999 2009, 49, 84-96.

1000 (45) Korb, O.; Stützle, T.; Exner, T. E. PLANTS: application of ant 1001 colony optimization to structure-based drug design. Lecture. Notes. in. 1002 Comput. Sci. 2006, 4150, 247-258.

1003 (46) Korb, O.; Stützle, T.; Exner, T. E. An ant colony optimization 1004 approach to flexible protein-ligand docking. Swarm. Intell. 2007, 1, 1005 115-134.

1006 (47) Hariharan, P. C.; Pople, J. A. The influence of polarization 1007 functions on molecular-orbital hydrogenation energies. Theoret. 1008 Chimica. Acta. 1973, 28, 213-222.

1009 (48) Francl, M. M.; Pietro, W. J.; Hehre, W. J.; Binkley, J. S.; 1010 DeFrees, D. J.; Pople, J. A.; Gordon, M. S. Self-consistent molecular 1011 orbital methods. XXIII. A polarization-type basis set for second-row 1012 elements. J. Chem. Phys. 1982, 77, 3654-3665.

1013 (49) Krishnan, R.; Binkley, J. S.; Seeger, R.; Pople, J. A. Self1014 consistent molecular orbital methods. XX. A basis set for correlated 1015 wave functions. J. Chem. Phys. 1980, 72, 650-654.

1016 (50) Boys, S.; Bernardi, F. The calculation of small molecular 1017 interactions by the differences of separate total energies. some 1018 procedures with reduced errors. Mol. Phys. 1970, 19, 553-566.

1019 (51) Frisch, M. J.; Trucks, G. W.; Schlegel, H. B.; Scuseria, G. E.; 1020 Robb, M. A.; Cheeseman, J. R.; Scalmani, G.; Barone, V.; Petersson, G. 1021 A.; Nakatsuji, H.; Li, X.; Caricato, M.; Marenich, A.; Bloino, J.; 1022 Janesko, B. G.; Gomperts, R.; Mennucci, B.; Hratchian, H. P.; Ortiz, J. 1023 V.; Izmaylov, A. F.; Sonnenberg, J. L.; Williams-Young, D.; Ding, F.; 1024 Lipparini, F.; Egidi, F.; Goings, J.; Peng, B.; Petrone, A.; Henderson, 1025 T.; Ranasinghe, D.; Zakrzewski, V. G.; Gao, J.; Rega, N.; Zheng, G.; 1026 Liang, W.; Hada, M.; Ehara, M.; Toyota, K.; Fukuda, R.; Hasegawa, J.; 1027 Ishida, M.; Nakajima, T.; Honda, Y.; Kitao, O.; Nakai, H.; Vreven, T.; 1028 Throssell, K.; Montgomery, Jr., J. A.; Peralta, J. E.; Ogliaro, F.; 1029 Bearpark, M.; Heyd, J. J.; Brothers, E.; Kudin, K. N.; Staroverov, V. N.; 1030 Keith, T.; Kobayashi, R.; Normand, J.; Raghavachari, K.; Rendell, A.; 1031 Burant, J. C.; Iyengar, S. S.; Tomasi, J.; Cossi, M.; Millam, J. M.; Klene, 1032 M.; Adamo, C.; Cammi, R.; Ochterski, J. W.; Martin, R. L.; 1033 Morokuma, K.; Farkas, O.; Foresman, J. B.; Fox, D. J. Gaussian 09, 1034 revision E.01; Gaussian Inc: Wallingford, CT, 2009.

1035 (52) Korkmaz, B.; Attucci, S.; Juliano, M. A.; Kalupov, T.; Jourdan, 1036 M. L.; Juliano, L.; Gauthier, F. Measuring elastase, proteinase 3 and 1037 cathepsin G. Nat. Protoc. 2008, 3, 991-1000. 